\title{
Investigations of $\mathrm{CO}_{2}$-water wettability of coal: NMR relaxation
}

method

\author{
Xiaoxiao Sun ${ }^{a, b}$, Yanbin Yao ${ }^{a, b^{*}}$, Dameng Liu ${ }^{a, b}$, Yingfang Zhou ${ }^{c}$

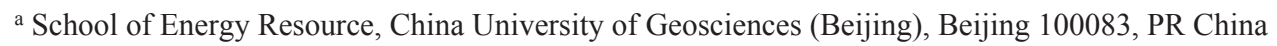 \\ ${ }^{b}$ Coal Reservoir Laboratory of National Engineering Research Center of CBM Development \& Utilization, \\ University of Geosciences, Beijing 100083, PR China \\ ${ }^{\mathrm{c}}$ School of Engineering, University of Aberdeen, Aberdeen, AB243UE, United Kingdom
}

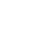

\begin{abstract}
Carbon geo-sequestration (CGS) and recovery enhancement with carbon dioxide injection $\left(\mathrm{CO}_{2^{-}}\right.$ ECBM) have brought increasing focus on the $\mathrm{CO}_{2}$ and water wettability of coal. The $\mathrm{CO}_{2}$ and water contact angles measured using existing conventional methods, such as the pendent drop tilting plate technique and the captive-bubble technique, show low reproducibility due to coal heterogeneity and operational complexity. In this study, a novel NMR-based approach was developed to evaluate the $\mathrm{CO}_{2}$ and water wettability of coal. The experimental results of nine bituminous and anthracite coals show that water wettability can be linearly correlated with the changes of the $T_{2}$ spectra peak positions. Based on the measured contact angle from the profile of the water adhering to the coal powder disc and the $T_{2}$ from the NMR of coal powder, we proposed a linear formulation to evaluate the contact angle using the change of $T_{2 \mathrm{~g}}$ of P3. Using this method, we analyzed the $\mathrm{CO}_{2}$-water wettability characteristics of coal. The results show that $\mathrm{CO}_{2}$ reduces the water wettability of coal. Low temperature and/or high $\mathrm{CO}_{2}$ pressure can enhance the $\mathrm{CO}_{2}$ wettability of coal. The change of water-coal wetting behavior with injection of $\mathrm{CO}_{2}$, is resulted by three factors: change of $\mathrm{CO}_{2}$ adsorption capacity of coal, change of interfacial tension, and dissolution of $\mathrm{CO}_{2}$ in water. This study makes it possible to evaluate changes in the water and $\mathrm{CO}_{2}$ wettability of coal, which is essential for evaluating the fluid-interaction mechanisms during the process of carbon geo-sequestration and enhanced coalbed methane recovery with carbon dioxide injection.
\end{abstract}

Keywords: $\mathrm{CO}_{2}$ sequestration; coalbed methane; coal; wettability; relative permeability

\section{Introduction}

Coal seams offer great potential for carbon geo-sequestration (CGS) with the accompanying benefit of recovery enhancement with carbon dioxide injection $\left(\mathrm{CO}_{2}\right.$-ECBM) (Ozdemir, 2009; Gentzis, 2000; Busch and Gensterblum, 2011). $\mathrm{CO}_{2}$ sequestration into coalbeds is largely controlled by the interactions between the coal matrix and $\mathrm{CO}_{2}$ and other reservoir fluids. In particular, the wettability of coal controls the pore scale fluid configuration and thus has a strong effect on capillary pressure, relative permeability and fluid invasion mechanisms (Chalbaud et al, 2006; Chaturvedi et al., 2009; Han et al., 2010; Iglauer et al., 2015; Zhou et al., 2016).

In the context of reservoir engineering, coalbed methane (CBM) reservoirs consist of cleats and matrix pores that are saturated with water: fluid flows in large cleats according to Darcy's law, 
whereas the diffusion-driven transport of gas occurs in coal micropores. The performance of $\mathrm{CO}_{2}$ for CGS or $\mathrm{CO}_{2}$-ECBM may be different for hydrophobic (gas-wet) and hydrophilic (water-wet) reservoirs. For a hydrophobic reservoir, micropores are occupied by gas, which leads to the much faster transport of the injected gas into the coal matrix. In contrast, if pores are filled with water, the transport of the injected gas in a hydrophilic reservoir is very slow due to the difficulty of gas diffusion through the water (Siemons et al., 2006; Kaveh et al., 2012). Hence, it is essential to quantify the wettability of coal to improve our understanding of the mechanisms of gas/water flow in coal seams.

Several quantitative and qualitative methods were used to evaluate the wettability of rock, including the contact angle measurement (Johnson and Dettre, 1969), the Amott method (Amott, 1959), the USBM wettability index (Donaldson et al., 1969), spontaneous imbibition (Bobek et al., 1958), the flotation method (American Petroleum Institute, 1962), displacement capillary pressure (Benner et al., 1942) and others (Meng et al., 2017). Among these methods, the Amott, USBM wettability index and displacement capillary pressure methods measure wettability by operating displacement tests. However, it is extremely difficult to perform these tests in unconventional lowpermeable samples, such as coal and gas shale (Xu and Dehghanpour, 2014; Iglauer, 2017), which thus limits their application to wettability measurements. The spontaneous imbibition rate/volume test allows us to indirectly indicate the wettability of coal and gas shale (Gao and Hu, 2016), but it fails to obtain any quantitative index for wettability characterization. Similarly, the flotation method, which is a fast and simplified operations measurement, is strongly influenced by coal particle size and the distribution of coal powder on the water, even though it is commonly used in the coal cleaning and flotation industry (Fuerstenau et al., 1987). Moreover, determining the immersion time in the flotation method is subjective and depends on personnel experience since there is no explicit standard of judgment on the immersion time.

The contact angle measurement is the most commonly used method for research of the wettability of coal (Wei et al., 1992; Orumwense, 1998; Anderson, 1986; Arnold and Aplan, 1989). However, the evaluated coal wettability may sometimes be inaccurate using the contact angle measurement because coal is an extremely heterogeneous material with significant variation in its physical and chemical properties, even on a polished coal sample surface. According to Keller (1987), the coal compositions of paraffinic hydrocarbon, aromatic carbon, and minerals are strongly hydrophobic, intermediate water-wet and strongly water-wet, respectively. Therefore, the heterogeneity in coal composition can result in high wettability heterogeneity with non-uniform spatial contact angle distribution in a coal sample (Wei et al., 1992; Siemons et al. 2006). To reduce the uncertainty during wettability measurements resulting from coal heterogeneity, coal powder discs, instead of a polished raw coal surface, are normally used to measure the contact angle (He and Laskowski, 1992; Zhou et al., 2016). However, the effect of disc porosity on the contact angle has still not effectively been solved (He and Laskowski, 1992). Moreover, it is difficult to prepare the sample and to compress coal discs with a polished plane, especially for anthracite coal with low clay mineral content. Thus, it is urgent to develop a quantitative methodology, with simple operation and high accuracy, to determine the water wettability of coal to perform successful CGS and $\mathrm{CO}_{2}$-ECBM projects. 
In the context of CGS and $\mathrm{CO}_{2}$-ECBM, it is of great value to investigate variations in the water and $\mathrm{CO}_{2}$ wettability of coal that are affected by the in situ reservoir temperature and pressure, as well as the gas adsorption and solution (Saghafi et al., 2014b; Kaveh et al., 2012; Sakurovs and Lavrencic, 2011; Siemons et al., 2006). In the literatures, contact angle measurement methods, including the pendent drop tilting plate technique (Arif et al., 2016) and the captive-bubble technique (Kaveh, et al., 2011; Ibrahim and Nasr-El-Din, 2016), have been used to obtain water/gas wettability in high-pressure $\mathrm{CO}_{2}$-water conditions. According to the results of Siemons et al. (2006), Sakurovs and Lavrencic (2011) and Kaveh et al. (2012), the contact angles of $\mathrm{CO}_{2}$ gas bubbles against coal surfaces in water cells decrease with increasing gas pressure, indicating that the coal became more $\mathrm{CO}_{2}$-wet. Additionally, there is a linear relationship between the gas bubble contact angle and gas pressure (Sakurovs and Lavrencic, 2011). Arif et al. (2016) measured the advancing and receding water contact angles of different rank coals using the pendent drop technique. They found that the $\mathrm{CO}_{2}$ wettability is independent of coal rank, and it increases with gas pressure and decreases with temperature. In these works, the contact angle of water-coal or gas-coal is measured from the profile of the water/gas bubble adhering to the surface. There are two major challenges in these measurements: the first is conducting the measurement in a high-pressure water/gas filled cell, and the other is that the measurement must be completed quickly. However, it is problematic to perform the measurement quickly, especially for the captive gas bubble technique, as it requires enough time for $\mathrm{CO}_{2}$ to adsorb on the coal. Additionally, the fast measurement may induce uncertainty in the contact angle. Moreover, for the contact angle measurement by the captive gas bubble method, the dissolution of gas bubbles in water also introduces inaccuracy to the results (Saghafi et al., 2014a). In addition to the mentioned challenges, the measured contact angle also depends on the gas bubble size. More specifically, smaller bubbles have higher capacity to wet coal (Saghfi et al., 2014b). In general, conventional contact angle measurement methods are not capable of evaluating the wettability of real water- $\mathrm{CO}_{2}$-coal systems in reservoirs.

The low field ${ }^{1} \mathrm{H}$ Nuclear Magnetic Resonance (NMR) technique has been successfully used to quantitatively evaluate the wettability of porous media, such as conventional hydrocarbon reservoirs (Bortolotii et al., 2009; Johannesen et al., 2007; Zhang et al., 2000; Connolly et al., 2017) and soil (Manalo and Kantzas, 2003). For example, a recent research by Connolly et al. (2017) demonstrated that the successful use of the NMR to quantify capillary trapping during dynamic sandstone core flooding experiments at reservoir conditions. However, this method has not been applied successfully to measure the water-gas wettability of coal. In this work, we applied the NMR method to quantitatively characterize the wettability of coal. In contrast to existing methods, the NMR technique is nondestructive, fast and makes real-time measurements, in addition to providing reliable results. We also evaluate the changes in water wettability of coal under different $\mathrm{CO}_{2}$ pressures and temperatures, which makes it possible to disclose the in situ interactions of fluids (water and $\mathrm{CO}_{2}$ ) with coal in reservoir conditions. This study is significant for the following in-depth investigation of the potential effects of $\mathrm{CO}_{2}$ and water wettability of coal on CGS and $\mathrm{CO}_{2}$-ECBM. 


\section{Samples and methods}

122

123

124

125

126

127

128

129

130

131

132

133

134

135

136

137

138

139

140

141

142

143

144

145

146

\subsection{Samples}

Nine coal block samples were collected from the underground coal mines of the Tarim, Ordos and Qinshui basins, China. All samples were carefully packed and immediately transported to the laboratory for vitrinite reflectance, maceral analyses and proximate analyses.

Six of the selected samples were crushed to powders of $0.18-0.25 \mathrm{~mm}$ in size. After moistureequilibrium pretreatment, these powdered samples were conducted for $\mathrm{CO}_{2}$ isothermal adsorption at a constant temperature of $25{ }^{\circ} \mathrm{C}$ and under pressures of up to $4.9 \mathrm{MPa}$ following the Chinese GB/T 19560-2004 procedure.

\subsection{Contact angle measurement}

Contact angle measurements were performed on the high-pressure compressed disc artificial surface made from the powdered coal. Since coal is an extremely heterogeneous medium consisting of different macerals and minerals that have different surface properties, the crushed powder samples can average the surface of coal with different organic and in-organic compositions. To form a much smoother surface for the contact angle measurement, we used a very small particle size $(0.074 \mathrm{~mm})$ to prepare the powder samples. Each powder sample was dried in a vacuum-oven at $80{ }^{\circ} \mathrm{C}$ for $6 \mathrm{~h}$ and compacted at $30 \mathrm{MPa}$ to form the coal discs. The compacted coal discs were kept in a vacuum container for constant angle measurements.

Contact angle measurements were conducted using an automatic contact angle meter equipped with 3 mega-pixel cameras and an LED light source. A special syringe and needle were used to fix the volume of the droplet to $10 \mu \mathrm{L}$ to exclude the impact of drop size on the contact angle measurement. The profile of the drop on the coal discs was photographed through a zooming lens, and then the contact angle of the drop was measured (Fig. 1). The representative contact angles for each sample are the mean values of the contact angles measured on 30 different spots on each disc. 
(a)

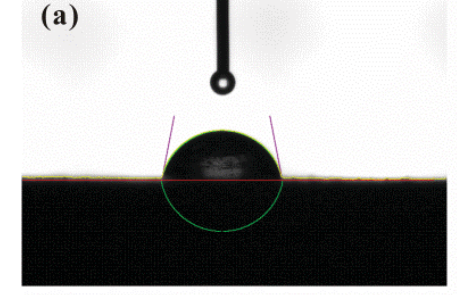

(d)

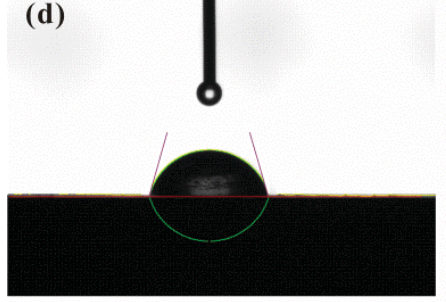

(g)

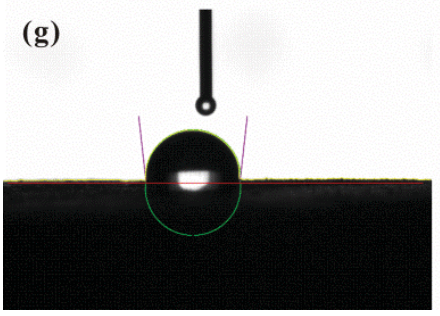

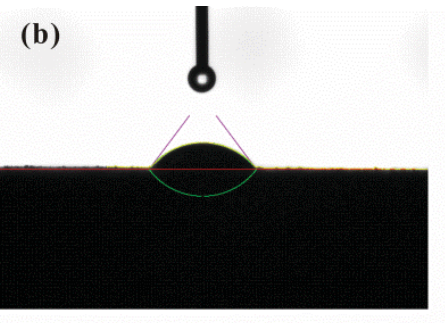

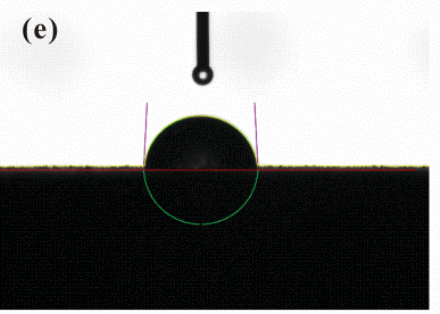

(h)

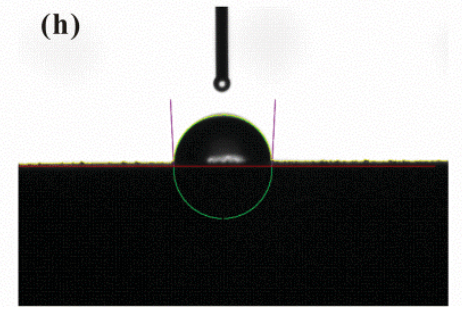

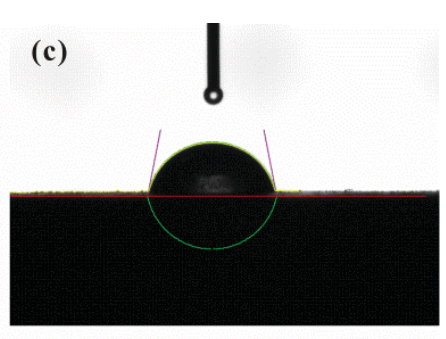

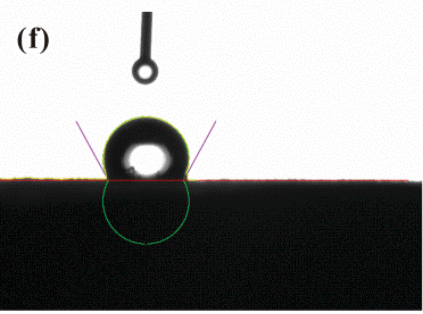

(I)

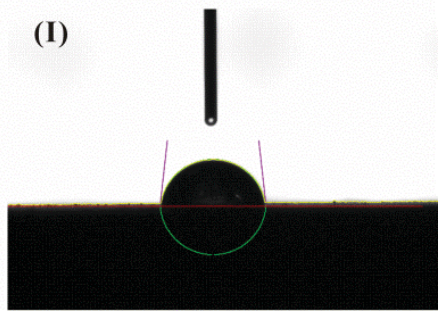

Fig. 1. Photographs of fluid-coal profiles for 9 samples (a-TA; b-FK; c-YX; d-SYQ; e-CYH; f-HY; g-GH; h-SJZ; i-WTP).

\subsection{NMR measurements}

The samples used for NMR measurements are powdered samples with coal particles of 0.18$0.25 \mathrm{~mm}$. The powder samples were dried in a vacuum-oven at $80^{\circ} \mathrm{C}$ for $6 \mathrm{~h}$ and then were put into a special made poly-Teflon sample cell for the NMR measurement. For the powdered samples in the sample cell, there are two types of pore voids: the inter-particle voids between coal particles, and intra-particle porosity within individual particles. It is well-accepted that the intra-particle porosity is much smaller than the inter-particle voids; thus, the intra-particle porosity can be neglected. Therefore, the inter-particle void porosity of packed coal powder can be calculated by:

$$
\phi=1-\frac{m}{\rho V_{c}}
$$

where is the inter-particle void porosity; $V_{\mathrm{c}}$ is the volume of the poly-Teflon sample cell; $m$ is the powdered coal mass and $\rho$ is the coal density. To keep all the samples in vials with the same void porosity, the same volume of coal powder was prepared by measuring the coal density $\rho$ and coal powder weight. Then, we can obtain the same inter-particle void porosity by packing the coal powder with the same volume into the same vials. In this study, the inter-particle porosity of the sample, , remains constant at $30 \%$.

Four series of experiments, A-D, were completed (Table 1). For the sample preparation of the series A-D, coal powder and $1 \mathrm{~mL}$ of distilled water were put into the sample cell, and then the sample cell was wrapped with plastic sheeting to keep the surface water from evaporating and the coal powder from oxidizing. First, the wrapped sample cell was placed in the NMR magnetic coil 
for experiment series-A. In this series, the $T_{2}$ spectra of nine samples were measured every hour to monitor the change of water in the coal. Second, experiment series-B was conducted on 6 coal powder samples to study the effect of $\mathrm{CO}_{2}$ on the water wettability. In series-B, the relative changes of the $T_{2}$ spectra were measured at a constant 4-MPa $\mathrm{CO}_{2}$ gas pressure and experimental temperature of $25^{\circ} \mathrm{C}$. Third, in series-C, the operation for samples SYQ and WTP was the same as experiment series- $\mathrm{B}$ except for the $\mathrm{CO}_{2}$ pressures (2 and $6 \mathrm{MPa}$ ). Finally, experiment series-D was conducted for samples FK and GH with the same process as series-B except at different temperatures $\left(35\right.$ and $45^{\circ} \mathrm{C}$ ). The purpose of conducting series-D is to investigate the effects of temperature on the water and $\mathrm{CO}_{2}$ wettability of coal.

Table 1 Four experimental series and their experimental conditions

\begin{tabular}{ccccc}
\hline $\begin{array}{c}\text { Experiment } \\
\text { Series }\end{array}$ & Sample & Fluid & $\begin{array}{c}\text { Pressure } \\
(\mathrm{MPa})\end{array}$ & $\begin{array}{c}\text { Temperature } \\
\left({ }^{\circ} \mathrm{C}\right)\end{array}$ \\
\hline A & $\begin{array}{c}\text { TA,FK, YX, SYQ,CYH,HY } \\
\text { GH,SJZ,WTP }\end{array}$ & Water & 0.1 & 25 \\
B & TA,FK, SYQ, GH,SJZ,WTP & $\mathrm{CO}_{2}$ & 4 & 25 \\
C & SYQ, WTP & $\mathrm{CO}_{2}$ & 2 and 6 & 25 \\
D & FK, GH & $\mathrm{CO}_{2}$ & 4 & 35 and 45 \\
\hline
\end{tabular}

181

182

183

184

185

186

187

In this study, the Carr-Purcell-Meiboom-Gill (CPMG) sequence was used to measure the $T_{2}$ distributions. The parameters of the NMR measurement are as follows: the echo spacing is $0.3 \mathrm{~ms}$, the echo-train is 64 , the wait time is $3 \mathrm{~s}$ and the echo number is 18000 .

\section{Results and discussion}

\subsection{Characterization of coal samples}

The results of the vitrinite reflectance, maceral analyses and proximate analyses are listed in Table 2. The selected coals are high-volatile bituminous coal to anthracite coal, representing a broad range of coal ranks and litho-type compositions. The mean maximum vitrinite reflectance in oil $\left(R_{o}, \%\right)$ of the coal ranges from $0.8 \%$ to $3.13 \%$. The coal macerals are mainly characterized by intermediate to high vitrinite corresponding to intermediate to low inertinite, plus minor proportions of liptinite.

The results of the $\mathrm{CO}_{2}$ adsorption experiments are given in Table 3. The Langmuir volumes of the selected six coal samples range from 27.54 to $57.73 \mathrm{~m}^{3} / \mathrm{t}$ (as-received-base), with the minimum value for the sample TA.

Table 2 Results of petrological composition analysis and coal proximate analysis of selected coals. $R_{\mathrm{o}}{ }^{\mathrm{a}} \quad$ Maceral and mineral $\quad$ Proximate analysis

Sample

Basin Coalmine (vol. \%) (wt.\%, dry)

\begin{tabular}{cccccccc} 
& \multicolumn{1}{c}{ ID } & $\mathrm{V}^{\mathrm{b}}$ & $L^{\mathrm{b}}$ & $\mathrm{MM}^{\mathrm{b}}$ & $M_{\mathrm{ad}}^{\mathrm{c}}$ & $A_{\mathrm{ad}}^{\mathrm{c}}$ & $C_{\mathrm{daf}^{\mathrm{c}}}$ \\
& $(\%)$ & $(\%)$ & $(\%)$ & $(\%)$ & $(\%)$ & $(\%)$ & $(\%)$
\end{tabular}




\begin{tabular}{ccccccccccc}
\hline TA & Ordos & Mutataian & 0.8 & 66.5 & 21.4 & 7.9 & 4.2 & 1.74 & 9.75 & 72.94 \\
FK & Tarim & Fukang & 0.83 & 63.3 & 26.4 & 3.4 & 6.9 & 6.68 & 2.84 & 66.6 \\
YX & Qinshui & Yuanxiang & 0.9 & 70.1 & 21.7 & 3.5 & 4.7 & 1.19 & 11.38 & 71.72 \\
SYQ & Ordos & Shangyuquan & 0.95 & 65.3 & 23.2 & 5.4 & 6.1 & 4.13 & 23.5 & 73.12 \\
CYH & Qinshui & Changyuhe & 1.35 & 76.6 & 18.6 & 0.4 & 4.4 & 0.96 & 10.77 & 87.72 \\
HY & Qinshui & Heyang & 1.8 & 90.6 & 4.6 & 0 & 4.8 & 1.14 & 10.31 & 83.97 \\
GH & Qinshui & Guohua & 2.3 & 83.9 & 8.7 & 0 & 7.4 & 2.38 & 17.99 & 89.51 \\
SJZ & Qinshui & Shenjiazhuang & 2.77 & 80.6 & 10.4 & 0 & 9.0 & 1.03 & 14.64 & 85.06 \\
WTP & Qinshui & Wangtaipu & 3.13 & 89.2 & 2.2 & 0 & 8.6 & 1.42 & 18.08 & 97.47
\end{tabular}

198

199

200

201

202

203

204

205

206

207

208

209

210

211

212

213

214

Table 3 The $\mathrm{CO}_{2}$ isothermal adsorption analyses and contact angles of water on selected coal disc surfaces.

\begin{tabular}{cccccccccc}
\hline Sample ID & TA & FK & YX & SYQ & CYH & HY & GH & SJZ & WTP \\
\hline $\begin{array}{c}\text { Langmuir volume } \\
\left(\mathrm{m}^{3} / \mathrm{t}\right)\end{array}$ & 27.54 & 38.73 & - & 31.64 & - & - & 57.73 & 42.78 & 48.14 \\
$\begin{array}{c}\text { Langmuir pressure } \\
(\mathrm{MPa})\end{array}$ & 0.69 & 0.7 & - & 2.13 & - & - & 1.35 & 1.47 & 1.09 \\
\begin{tabular}{c} 
Contact angle $\left(^{\circ}\right)$ \\
\hline
\end{tabular} & 79 & 53 & 79 & 74 & 87 & 118 & 96 & 93 & 84 \\
\hline
\end{tabular}

The measured contact angles for the nine samples vary from $53^{\circ}$ to $118^{\circ}$ (Table 3 ). Coal sample FK is the strongest water-wet, with a contact angle of $53^{\circ}$, whereas HY is the weakest water-wet, with a contact angle of $118^{\circ}$. The contact angle is related to coal rank and coal petrological composition. As shown in Fig. 2, the contact angles increase with coal rank at $R_{\mathrm{o}}$ values of $0.8 \%$ $1.8 \%$, and then they decrease slightly with increasing coal rank at $R_{0}$ values of $>1.8 \%$. The maximum of the contact angle is observed at coal rank from medium-volatile bituminous coal to low-volatile bituminous coal, which agrees well with the results reported by Horsley and Smith (1951). Moreover, contact angles show a positive correlation with vitrinite group contents (Fig. 2) because the vitrinite group is more hydrophobic than the inertinite group (Arnold and Aplan, 1989). and liptinite, respectively, in coal maceral composition. MM is the volume percentage of minerals in the air-dry base. ${ }^{c} M_{\text {ad }}$ and $A_{\text {ad }}$ represent the air-dry-base moisture content and ash yield, respectively. $C_{\text {daf }}$ represents the dryash-free base fixed carbon content. 

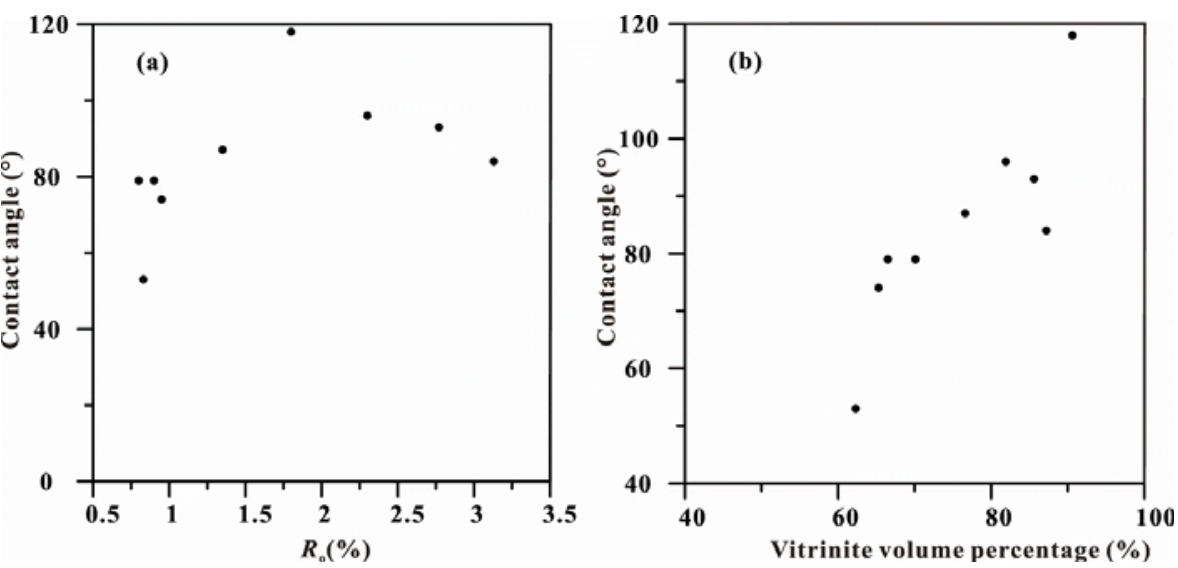

Fig. 2. The relationship between contact angles and a-mean maximum vitrinite reflectance in oil $\left(R_{\mathrm{o}}\right)$; b-volume percentage of the vitrinite group.

\subsection{Determination of contact angle by the NMR method}

\subsubsection{Changes of $T_{2}$ spectra after water addition}

According to the basics of NMR measurements, the $T_{2}$ of water in a homogeneous internal field gradient can be described by Eq. (2) (Howard et al., 1993; Kenyon et al., 1988),

$$
\frac{1}{T_{2}}=\frac{1}{T_{2 B}}+\rho_{2} \frac{S}{V}
$$

where $B$ is bulk relaxation; $\rho_{2}$ is the surface relaxivity and $S / V$ is the surface-to-volume ratio (Lowden et al., 1988). Bulk fluid relaxation relaxes slowly and signal peaks appear at longer relaxation times, which is an intrinsic property of the fluid. Surface relaxation relaxes rapidly and is affected by the interactions of the fluid with the surface (Coates et al., 1999; Yao et al., 2010, 2014).

The measured $T_{2}$ spectra of the coal powder samples with the addition of water indicate that different phases of water exist in the coal powder. As shown in the black solid line spectra in Fig. 3, there are three distinct $T_{2}$ spectrum peaks: P1, P2 and P3. P1, which is located at approximately $0.1-10 \mathrm{~ms}$, represents the water in adsorption pores (with diameters of less than $0.1 \mu \mathrm{m}$ ) of individual coal particles. P2, located at approximately 10-100 ms, results from the surface relaxation of water in the seepage pores (more than $0.1 \mu \mathrm{m}$ in diameter) of the individual coal particles (Sun et al., 2016). P3 (approximately 100-1000 ms) represents water in the inter-particle void space, which is dominated mainly by bulk water relaxation. Compared with the P1 and P3 peaks, the P2 peak appears to be too small. This means that the porosity of the seepage pores is relatively low in coal with a particle size of $0.2-0.3 \mathrm{~mm}$ (in diameter). Moreover, P2 is not detected for samples WTP and TA, which may result from the fast fluid exchange between bulk water and the water in the seepage pores. 

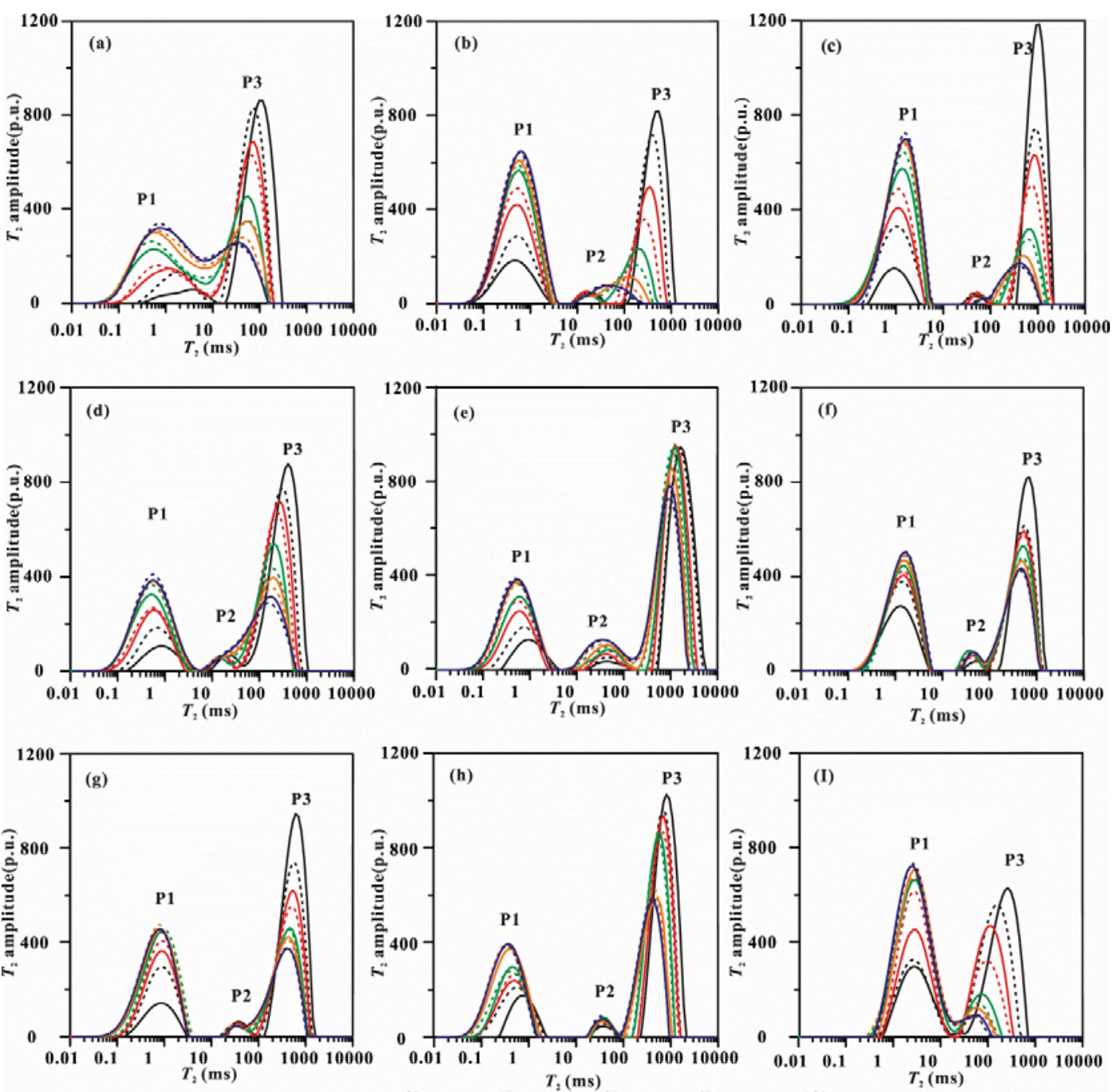

${ }^{2} 0 \mathrm{~h}$

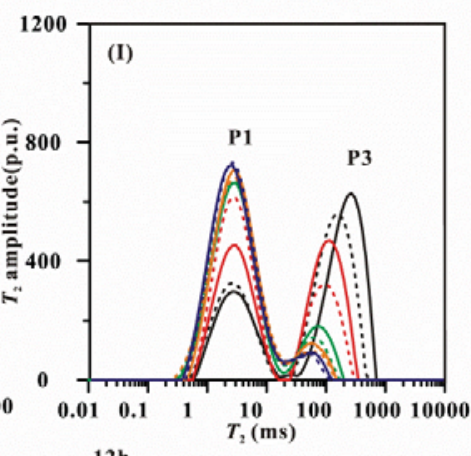

Fig. 3. $T_{2}$ spectra of coal samples after water addition (a-TA; b-FK; c-YX; d-SYQ; e-CYH; f-HY; g-GH; h-SJZ; i-WTP)

The different $T_{2}$ spectrum curves for the same coal sample in Fig. 3 show different water conditions within the coal sample, i.e., representing the movement of water in the coal powder with time. There is a notable trend of increasing P1 and decreasing P3 after the addition of water into the coal powder. Meanwhile, P3 shifts leftward (toward the fast relaxation part). This suggests that the bulk water in the inter-particle space moves into the intra-particle pores, leading to decreases in the area of $\mathrm{P} 3$ and increases in the area of $\mathrm{P} 1$. The changes of the P3 position indicate that the bulk water between individual particles spreads to more inter-particle surfaces. 
where $T_{2 \mathrm{~g}}$ is the weighted geometric average of the $T_{2}$ distribution, $T_{2 i}$ is the $i$ th transverse relaxation time, $A_{\text {total }}$ is the total signal amplitude of the $T_{2}$, and $A_{i}$ is the signal amplitude of the $i$ th $T_{2}$. A greater value of $T_{2 \mathrm{~g}}$ indicates that the fluid resides in larger pores or is more affected by the bulk phase; conversely, a smaller value reflects fluid residing in smaller pores. The change of $T_{2 \mathrm{~g}}$ indicates a shift of the $T_{2}$ spectra position, indicating the movement of fluid in pores (Guo and Kantzas, 2009). Thus, the $T_{2 \mathrm{~g}}$ of P3 is calculated to quantify the change in the peaks. Moreover, the normalized $T_{2 \mathrm{~g}}$ was used to measure the degree of peak changes for different coals.

Fig. 4 shows that the normalized $T_{2 \mathrm{~g}}$ of P3 decreases with water residence time for the nine coal samples. The reduction trends of $T_{2 \mathrm{~g}}$ are different from each other for these coal samples. For the same coal sample, the fastest decrease is noticed in the first 48 hours; then, the change decreases during 48-72 hours, which means the water in coal tends to approach an approximate equilibrium state after 48 hours. Thus, we assume that the water reaches an equilibrium state after 72 hours, when the change of the $T_{2 \mathrm{~g}}$ spectra between 60 to 72 hours can be neglected.

\subsubsection{Determination of coal wettability by NMR}

The ultimate normalized $T_{2 \mathrm{~g}}$ of P3 has a positive linear correlation against the measured contact angles for coal discs (Fig. 5). As shown in this figure, a smaller ultimate normalized $T_{2 \mathrm{~g}}$ of P3 value in the equilibrium state corresponds to a more water-wet coal sample. In contrast, a larger ultimate normalized $T_{2 \mathrm{~g}}$ of $\mathrm{P} 3$ value relates to a less water-wet coal. This is because for stronger water-wet coal, a large surface wettability force drives the water in the inter-particle space accesses into more coal particle surfaces. In this situation, the migration of water is represented by the leftward movement of $T_{2}$ distribution and a smaller $T_{2 \mathrm{~g}}$ value. We use the interfacial tension theory provided by Thomas Young (Young et al., 1805) to explain the mechanism of water migration. According to Young et al. (1805), the contact angle of a liquid drop on an ideal solid surface is defined by the mechanical equilibrium of the drop under the action of three interfacial tensions. The interactions between the three interfacial tensions are expressed by the Young-Laplace equation, 
where $\delta_{l g}$ is the gas-water interfacial tension; $\delta_{s g}$ is the gas-solid interfacial tension; $\delta_{l s}$ is the solidwater interfacial tension and $\theta$ is the contact angle of water on the solid surface. In Eq. (4), $\delta_{s g}-\delta_{l s}$ is defined as surface wettability tension, which is the driving force of water migration on coal particle surfaces.

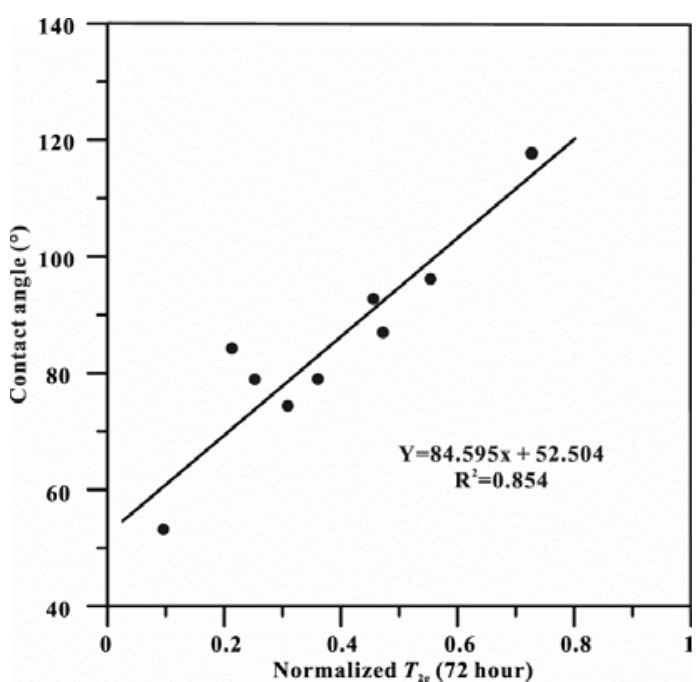

293

294 295

Fig. 5. The correlation between contact angles and ultimate normalized $T_{2 \mathrm{~g}}$ of $\mathrm{P} 3$ after the addition of water.

As mentioned above, for all samples, the inter-particle porosity and coal particle size are the same. Therefore, the different water spreading among coal powder results from different surface wettability tension for the coal samples. Moreover, the $\underline{\delta}_{l g}$ remains constant for different coal samples at the same conditions (temperature, pressure and media). Thus, there is a negative correlation between surface wettability tension and $\theta$. For stronger water-wet coal with a small contact angle, a large surface wettability force drives the water to spread onto more coal particle surfaces. When the water in the inter-particle space spreads on more particles, the $T_{2}$ relaxation is influenced more by surface relaxation and leads to the $T_{2}$ value becoming smaller. Conversely, in the weaker water-wet coal powder, the water spreads to less coal particle surfaces, leading to slighter $T_{2}$ changes. Therefore, the changes of the $T_{2 \mathrm{~g}}$ of P3 show a positive correlation with surface wettability tension. Note that the gravity effect can be neglected for different coal powders because we used the same inter-particle porosity, coal particle size and experimental operations in this study.

As shown in Fig. 5, the contact angle of water on the coal surface, $\theta$, could be correlated as a linear equation of $T_{2 \mathrm{~g}}$ of $\mathrm{P} 3$ at the end of the test ( $\mathrm{t}=72$ hours). The fitted linear correlation is given as below,

$\theta=84.6 \times T_{2 \mathrm{~g}}+52.5$

Eq. (5) is then applied as a general model to determine the contact angles of real coal samples based on the NMR measurements of the $T_{2 \mathrm{~g}}$ of P3.

\subsubsection{Uncertainty analysis of the model}

Assessing the reproducibility of the NMR experiments is important for evaluating the 
credibility of the proposed model. In this study, we chose sample SJZ to repeat the NMR experiments at $25{ }^{\circ} \mathrm{C}$. Two groups of reproducibility experiments were conducted for coal sample SJZ (Fig. 6a and 6b). Figure 6c compares the results from the two reproducibility experiments with those from experiment series-A. As shown in Fig. $6 \mathrm{c}$, the $T_{2 \mathrm{~g}}$ values of P3, at the equilibrium state of water ( 72 hours), are almost the same for the three groups of experiments. The absolute deviation between the three sets of data at 72 hours after water dripping is within $1 \%$ for sample SJZ, which is acceptable in terms of deviation; thus, the model of wettability determination by NMR experiments is repeatable for all other samples.
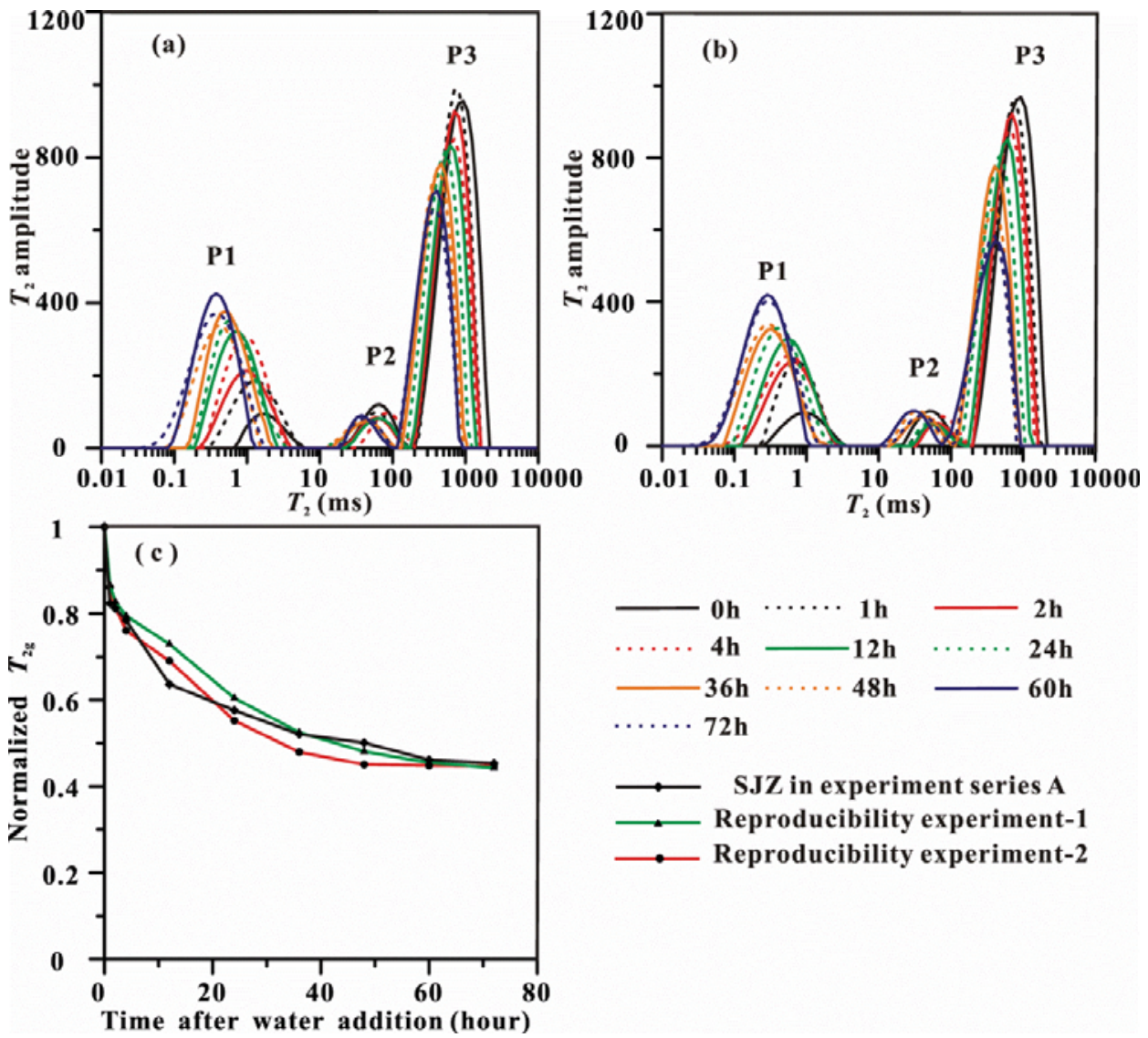

Fig. 6. a,b-Reproducibility experiments for the SJZ wettability measurement; c-The normalized $T_{2 \mathrm{~g}}$ of P3 peak decreases in the three groups of experiments.

However, there are two key uncertainties in the NMR wettability measurements. The first is related to the change in the coal mineral content during grinding and sieving. Jayaweera et al. (1989) concluded that ash content varied among different particle sizes, i.e., the ash content increased with decreasing mean particle diameter results from sieving method. In this study, we crushed and sieved using different size mesh sieves to get different size coal powders, and the remaining material on the topside sieve was crushed and sieved again. This procedure was continued until the whole portion eventually passed through the sieves. During the process of sieving, the minerals went through the sieves to smaller-sized coal powder. Thus, the mineral contents in the specific coal powder are slightly less than those of the raw coal samples. Another uncertainty is the coal oxidation during the 72-hour experiment. Although it is unavoidable, we attempted to keep the coal powder sample from oxidizing by accelerating the grinding operation 

and then keeping the coal powder in a vacuum.

\subsection{Effects of $\mathrm{CO}_{2}$ injection on the change of water wettability of coal}

After $\mathrm{CO}_{2}$ injection into the coal reservoir, the reservoir properties (e.g., pore size distribution, permeability and wettability) will change due to a series of physical and chemical reactions between coal, water and $\mathrm{CO}_{2}$ (Zhang et al., 2016; Iglauer, 2017). Thus, the laboratory analysis of water and the $\mathrm{CO}_{2}$ wettability of coal can provide a better understanding of the simulation of underground $\mathrm{CO}_{2}$ injection in the in situ reservoir.

In experiment series- $\mathrm{B}$, six representative samples were selected from the nine coal samples in experiment series-A. The coal powders were kept in $4 \mathrm{MPa} \mathrm{CO}_{2}$ after the addition of water, and then the $T_{2}$ spectra were measured to research the water wettability after the $\mathrm{CO}_{2}$ treatment. Figure 7 shows the changes of the $T_{2}$ spectra after the water addition in $\mathrm{CO}_{2}$ for the samples. Like the peak changes in experiment series-A, P1 increases and P3 decreases for all samples. Moreover, the P3 peak moves to the smaller $T_{2}$ with time. Comparing the normalized $T_{2 \mathrm{~g}}$ of P3 in experiment series-A and series-B for six samples shows that the normalized $T_{2 \mathrm{~g}}$ of P3 increases with the injection of $\mathrm{CO}_{2}$ (Fig. 8). As discussed in the previous section, the increase of $T_{2 \mathrm{~g}}$ indicates that the spread of water on coal particle surfaces becomes weak for all samples in $\mathrm{CO}_{2}$.

Experiment series-C and series-D were carried out to investigate the effect of pressure and temperature on the wettability changes of coal resulting from $\mathrm{CO}_{2}$ injection. Figure 9 shows the $T_{2}$ spectra changes with time for samples SYQ and WTP under $2 \mathrm{MPa}, 4 \mathrm{MPa}$ and $6 \mathrm{MPa} \mathrm{CO}_{2}$. Figure 10 shows the changes of normalized $T_{2 \mathrm{~g}}$ of $\mathrm{P} 3$ with time after the addition of $\mathrm{CO}_{2}$ at different pressures. With pressure increasing from $2 \mathrm{MPa}$ to $6 \mathrm{MPa}$, the normalized $T_{2 \mathrm{~g}}$ of $\mathrm{P} 3$ increases. The higher $\mathrm{CO}_{2}$ pressure has a greater effect on the water spread on coal particle surfaces for both the bituminous and anthracite coals, which indicates that the high $\mathrm{CO}_{2}$ pressure shows a positive effect on the decreases of water-wetting.

Figure 11 shows the change of $T_{2}$ spectra for samples $\mathrm{FK}$ and $\mathrm{GH}$ with time at $25^{\circ} \mathrm{C}, 35^{\circ} \mathrm{C}$ and $45^{\circ} \mathrm{C}$. With increasing temperature, the change ranges of the $\mathrm{P} 3$ area and position become larger. As shown in Fig. 12, after the addition of water and at different temperatures, the curves of normalized $T_{2 \mathrm{~g}}$ of P3 first decrease and finally tend to maintain a certain value. Moreover, the higher the temperature, the smaller the $T_{2 \mathrm{~g}}$ of $\mathrm{P} 3$, i.e., high temperature has a negative effect on the decrease of coal water wettability. 

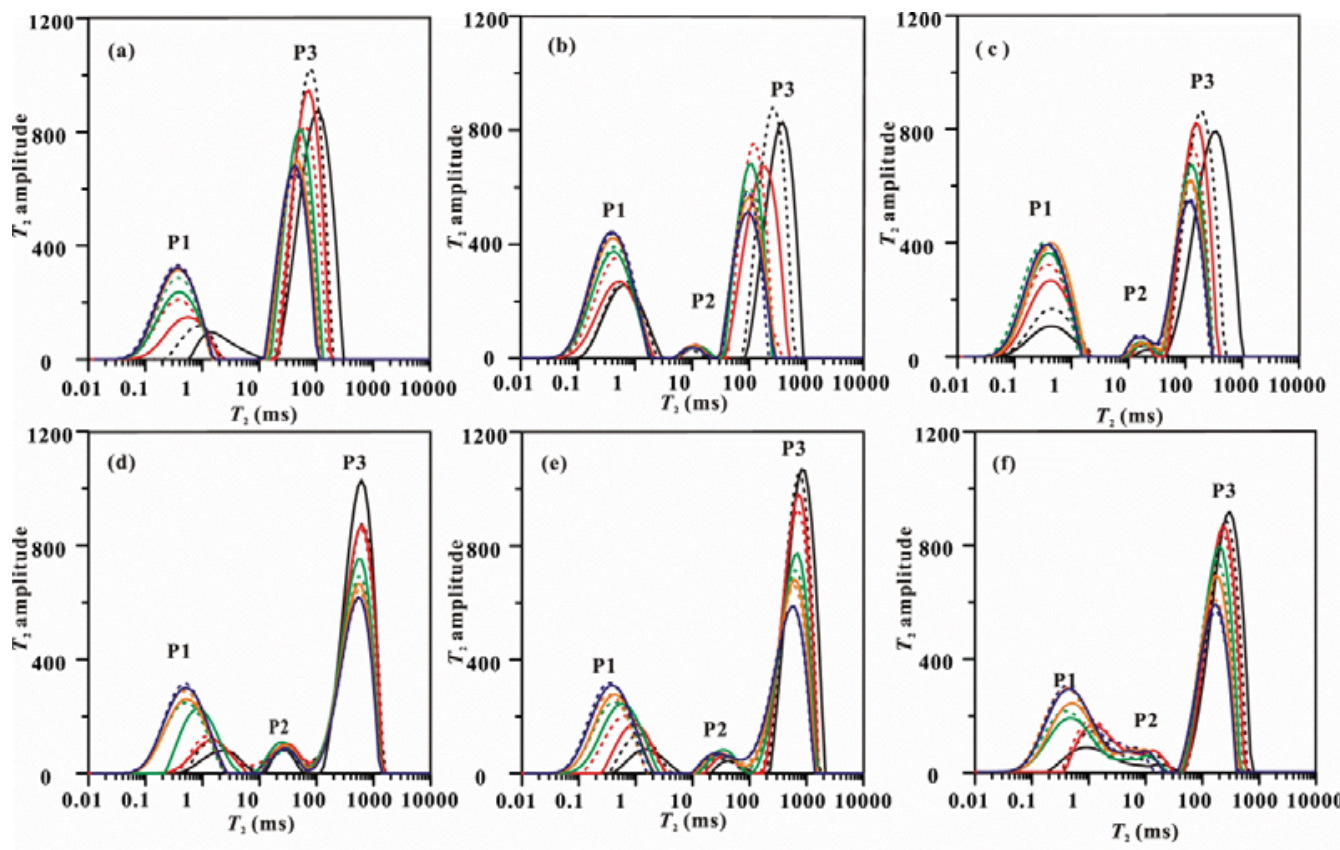

Fig. 7. $T_{2}$ spectra of coal samples after water addition in $4 \mathrm{MPa} \mathrm{CO}_{2}$ (a-TA; b-FK; c-SYQ; d-GH; e-SJZ; f-WTP)

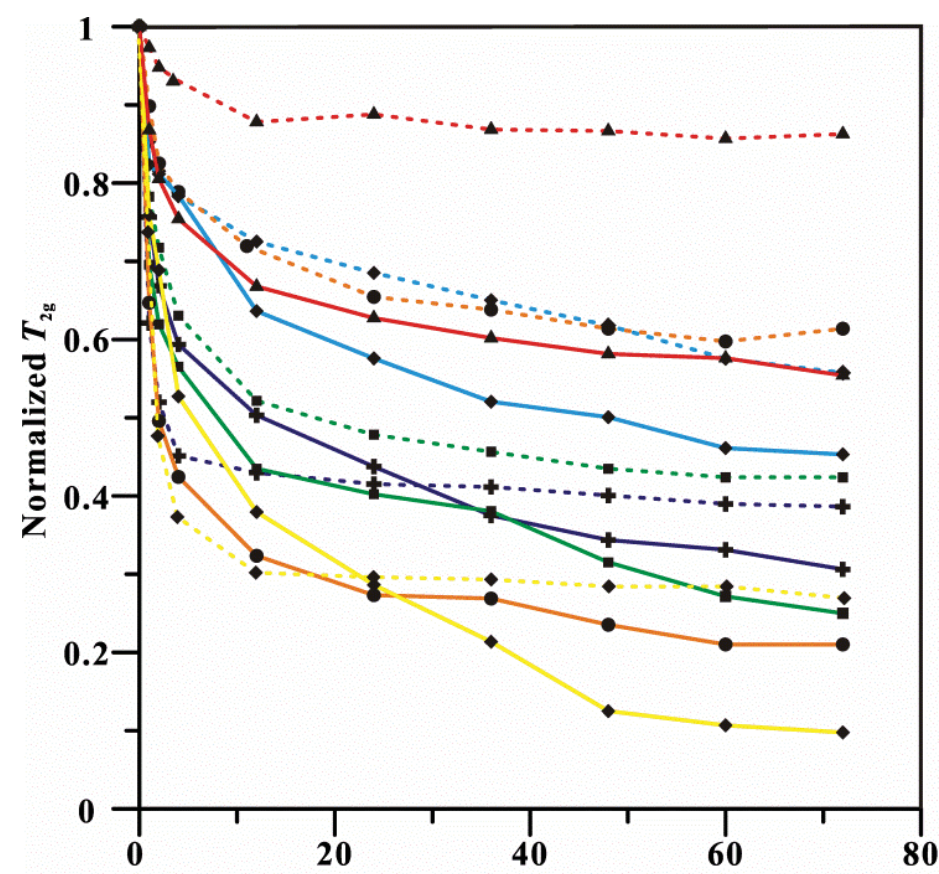

Time after water addition (hour)
$T_{2 \mathrm{~g}}$ of $\mathrm{P3}$ in atmosphere

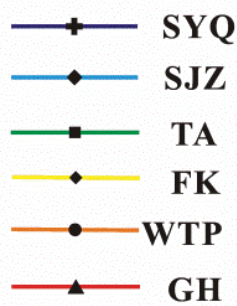

$T_{2 \mathrm{~g}}$ of P3 in $4 \mathrm{MPa} \mathrm{CO}$

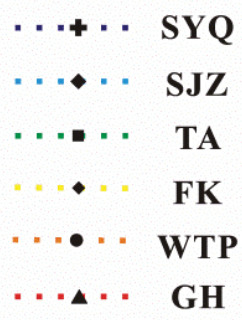

Fig. 8. The normalized $T_{2 \mathrm{~g}}$ of $\mathrm{P} 3$ decreases under atmospheric and $\mathrm{CO}_{2}$ conditions 

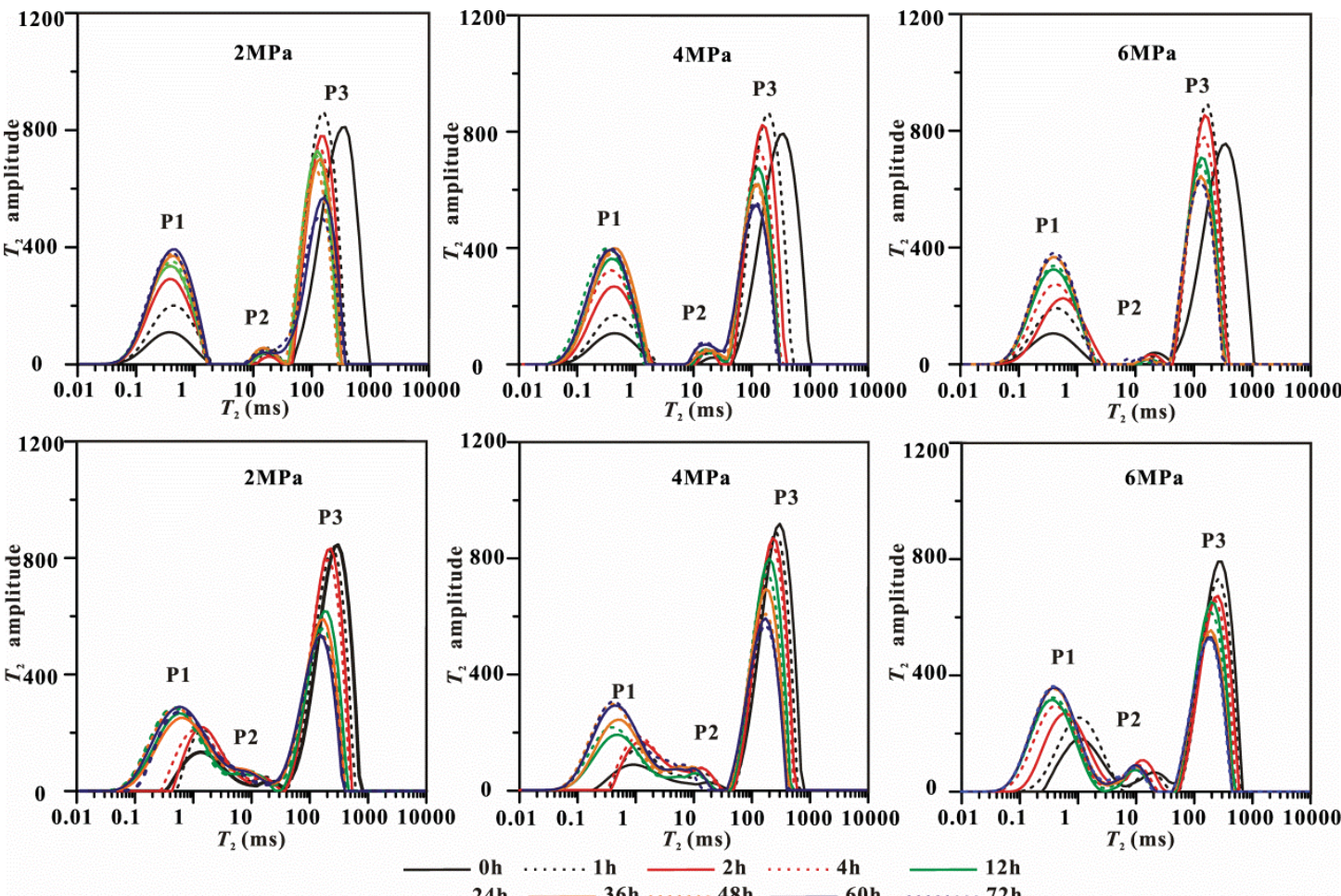

$1 \mathrm{~h}-2 \mathrm{~h}$
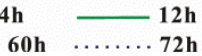

Fig. 9. $T_{2}$ spectra of coal samples at different $\mathrm{CO}_{2}$ pressures after water addition (a,b,c-SYQ; d,e,f-WTP) 379
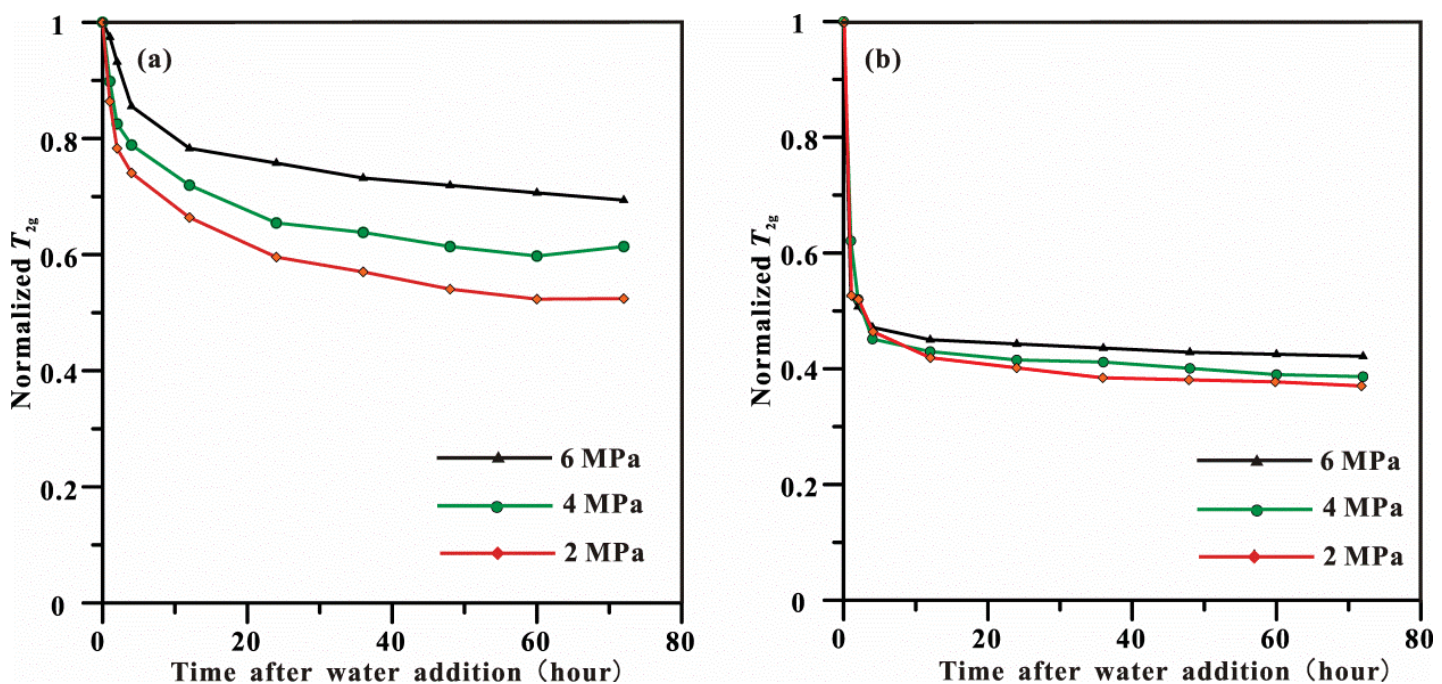

Fig. 10. The normalized $T_{2 \mathrm{~g}}$ of $\mathrm{P} 3$ decreases at different $\mathrm{CO}_{2}$ pressures (a-WTP; b-SYQ) 

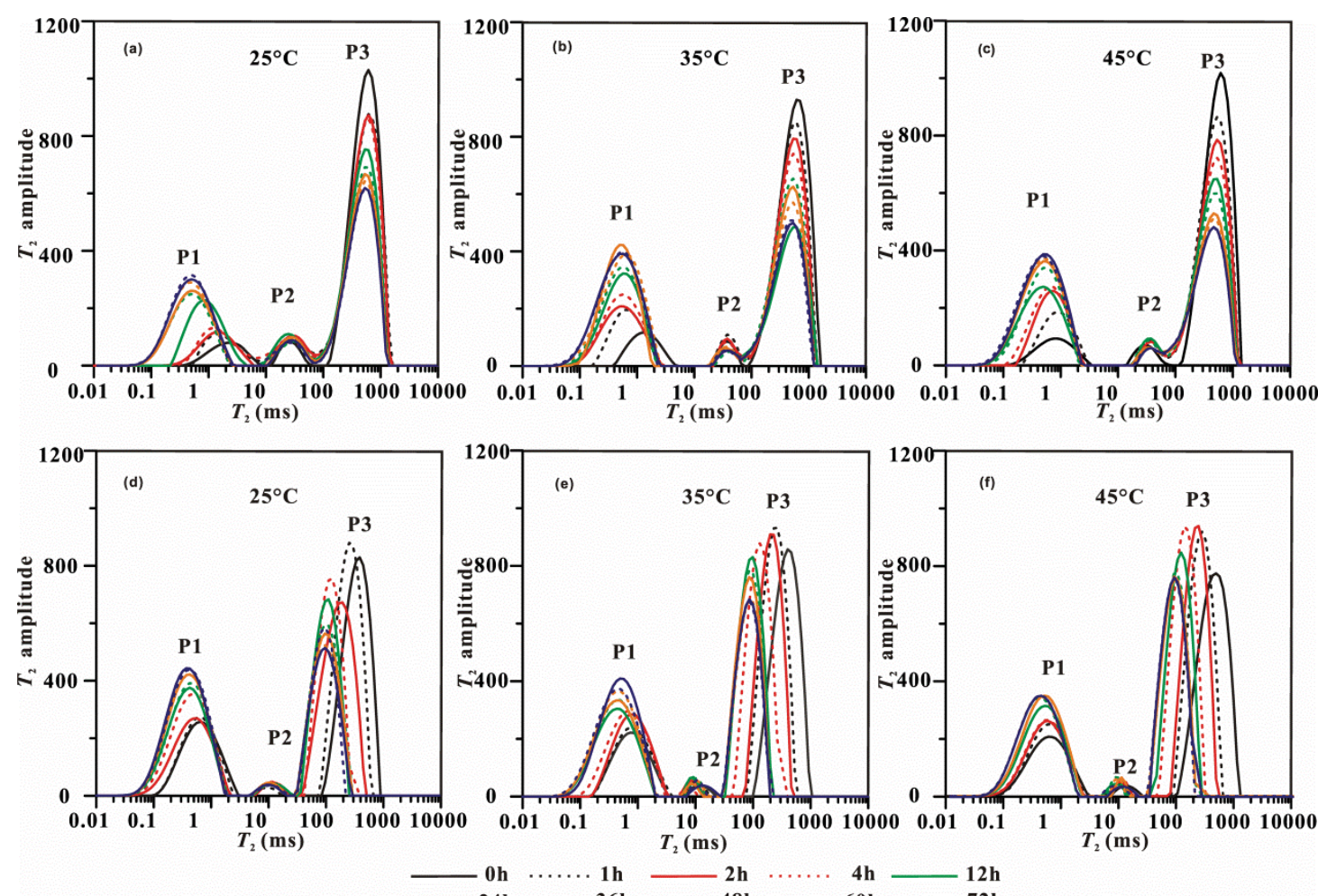

$4 \mathrm{~h}$

$12 \mathrm{~h}$

Fig. 11. $T_{2}$ spectra of coal samples after water addition at different temperatures (a, b, c-GH; d, e, f-FK)
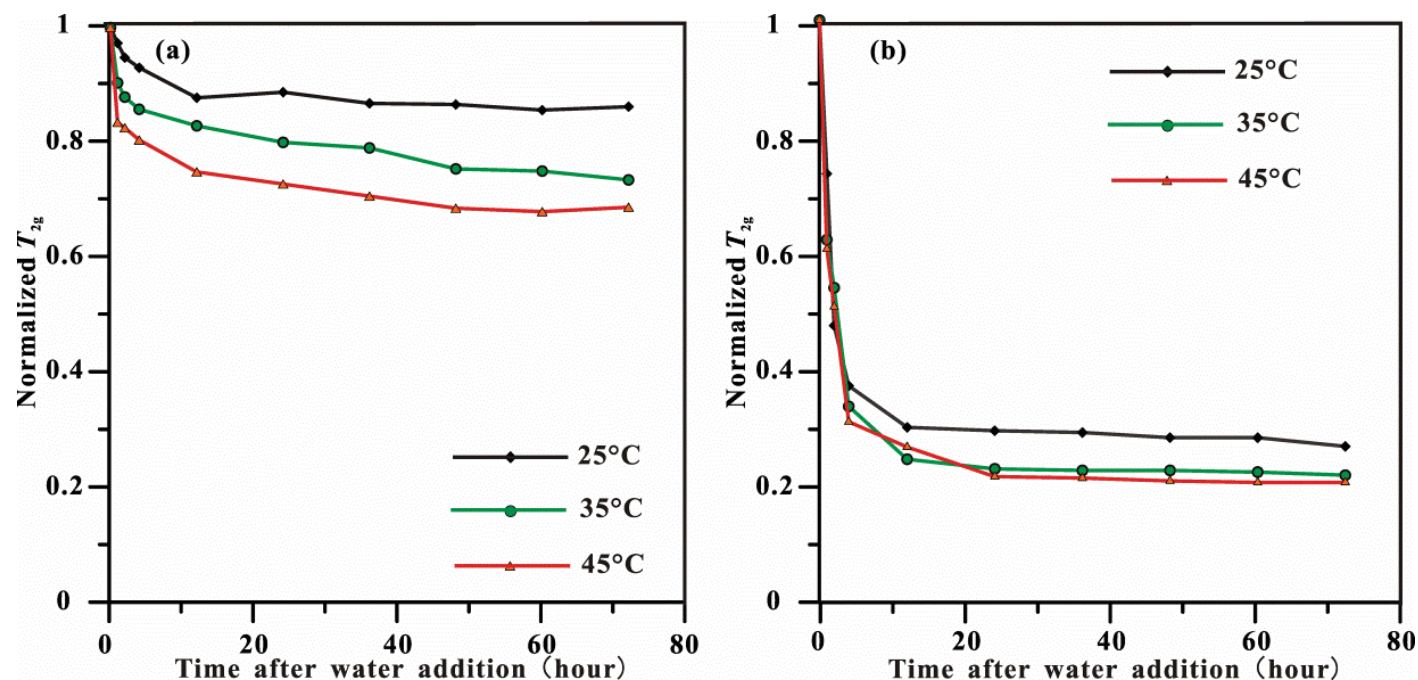

Fig. 12. The normalized $T_{2 \mathrm{~g}}$ of $\mathrm{P} 3$ decreases with $\mathrm{CO}_{2}$ at different temperatures (a-GH; b-FK)

\subsection{Discussion}

\subsubsection{Effect of coal properties on water and $\mathrm{CO}_{2}$ wettability}

The results of experiment series-B show that the $T_{2 \mathrm{~g}}$ of $\mathrm{P} 3$ increases with $\mathrm{CO}_{2}$ injection and varies with different coal rank. Using Eq. (5) and the ultimate normalized $T_{2 \mathrm{~g}}$ of P3, we can obtain the contact angle of water in the 4-MPa $\mathrm{CO}_{2}$ condition. As shown in Table 4, the contact angle of water increases with $\mathrm{CO}_{2}$ injection, indicating that water wettability becomes weak for both anthracite and bituminous coals after being exposed to $\mathrm{CO}_{2}$. However, the degree of change in wettability varies, and it is defined by the difference of the water contact angle between 
experiment series-A and series-B $(\Delta \theta)$ (Table 4).

Table 4 Water contact angle calculations using Eq. (5) in the series-A and series-B experiments

\begin{tabular}{ccccccc}
\hline Sample ID & TA & FK & SYQ & GH & SJZ & WTP \\
\hline $\begin{array}{c}\text { water contact angle } \theta_{1}\left(^{\circ}\right) \\
(\text { experiment series-A) }\end{array}$ & 73.7 & 60.8 & 78.4 & 99.4 & 90.8 & 70.3 \\
$\begin{array}{c}\text { water contact angle } \theta_{2}\left(^{\circ}\right) \\
(\text { experiment series-B) }\end{array}$ & 88.4 & 84.7 & 85.2 & 125.5 & 99.7 & 104.4 \\
$\Delta \theta\left(\theta_{2}-\theta_{1}\right)$ & 14.7 & 23.9 & 6.8 & 26.1 & 8.9 & 34.1 \\
\hline
\end{tabular}

400

The $\Delta \theta$ is correlated with the $\mathrm{CO}_{2}$ adsorption capacity, vitrinite content, fixed carbon content, and vitrinite reflectance of coal (Fig. 13). There is a slight positive correlation between the increase of the water contact angle and the $\mathrm{CO}_{2}$ adsorption volume (Fig. 13a). Sakurovs and Lavrencic (2011) and Kaveh et al. (2011) suggested that the water-coal wetting behavior was affected by the adsorption of $\mathrm{CO}_{2}$ on the coal surface. Although there is no proof of a direct relationship between $\mathrm{CO}_{2}$ wettability and $\mathrm{CO}_{2}$ adsorption, it can be assumed that coal with a large volume $\mathrm{CO}_{2}$ adsorption capacity has stronger $\mathrm{CO}_{2}$ wettability. Since adsorption is the dominant storage mechanism in coal, and it typically accounts for $98 \%$ of the total gas stored, further investigation is required to establish the relationship between $\mathrm{CO}_{2}$-wettability and $\mathrm{CO}_{2}$-adsorption. Moreover, the adsorption of $\mathrm{CO}_{2}$ into micropores in the coal matrix leads to a significant decrease in permeability, which may limit the Darcy flow of the $\mathrm{CO}_{2}$. A recent research by Zhang et al. (2016) demonstrated that $\mathrm{CO}_{2}$ injection can change coal microstructure and permeability. Thus, further investigation is required to affirm whether the coal matrix swelling due to $\mathrm{CO}_{2}$ injection is another reason for the change of $\mathrm{CO}_{2}$ wettability or not.

The contact angle changes also show a slight positive relationship with vitrinite volume and fixed carbon content (Fig. 13b and c). As mentioned above, the vitrinite group is hydrophobic. Moreover, Sakurovs and Lavrencic (2011) found that the fixed carbon content increased the hydrophobicity of coal. Thus, those weak water-wet contents of coal may become more $\mathrm{CO}_{2}$-wet during $\mathrm{CO}_{2}$ injection. The relationship between coal rank (vitrinite reflectance) and $\Delta \theta$ is relatively weak (Fig. 13d).

\subsubsection{The effect of pressure on water and $\mathrm{CO}_{2}$ wettability}

Experiment series-C shows that higher $\mathrm{CO}_{2}$ pressure has a greater effect on the decrease of water wettability for both bituminous and anthracite coals, i.e., the coals become more $\mathrm{CO}_{2}$-wet. To compare the water wettability of coal at different pressures, we calculated the contact angles of water using Eq. (5). The results are presented in Fig. 14. With increasing pressure of 0.1-6 MPa, the contact angle of water increased from $70.3^{\circ}$ to $111.2^{\circ}$ for WTP and from $78.4^{\circ}$ to $88.2^{\circ}$ for SYQ, which indicates the increase of $\mathrm{CO}_{2}$ wettability. The increase of $\mathrm{CO}_{2}$ wettability and the decrease of water wettability with $\mathrm{CO}_{2}$ pressure are consistent with the existing experimental data. 
captive bubble technique for low to medium rank coal $\left(R_{\mathrm{o}}\right.$ ranged from 0.62 to 1.4$)$ and found an increase in $\mathrm{CO}_{2}$ wettability with pressure for all samples. Siemons et al. (2006) measured the $\mathrm{CO}_{2}$ contact angle for anthracite coal and found that it became $\mathrm{CO}_{2}$-wet $(\theta>90)$ at $0.26 \mathrm{MPa}$. However, Arif et al. (2016) determined that semi-anthracite became weakly $\mathrm{CO}_{2}$-wet at approximately 7 $\mathrm{MPa}(\theta>110)$. Kaveh et al. (2011) found that semi-anthracite become $\mathrm{CO}_{2}$-wet at $5.7 \mathrm{MPa}$ and that high-volatile bituminous coal become $\mathrm{CO}_{2}$-wet at $8.7 \mathrm{MPa}$. In our research, anthracite coal WTP became $\mathrm{CO}_{2}$-wet at pressures of less than $2 \mathrm{MPa}$; however, bituminous coal SYQ became $\mathrm{CO}_{2}$ wet at pressures of $>6 \mathrm{MPa}$. As shown in Fig. 14, the contact angle changes more for anthracite than it does for bituminous coal with increasing pressure from 0 to $6 \mathrm{MPa}$.
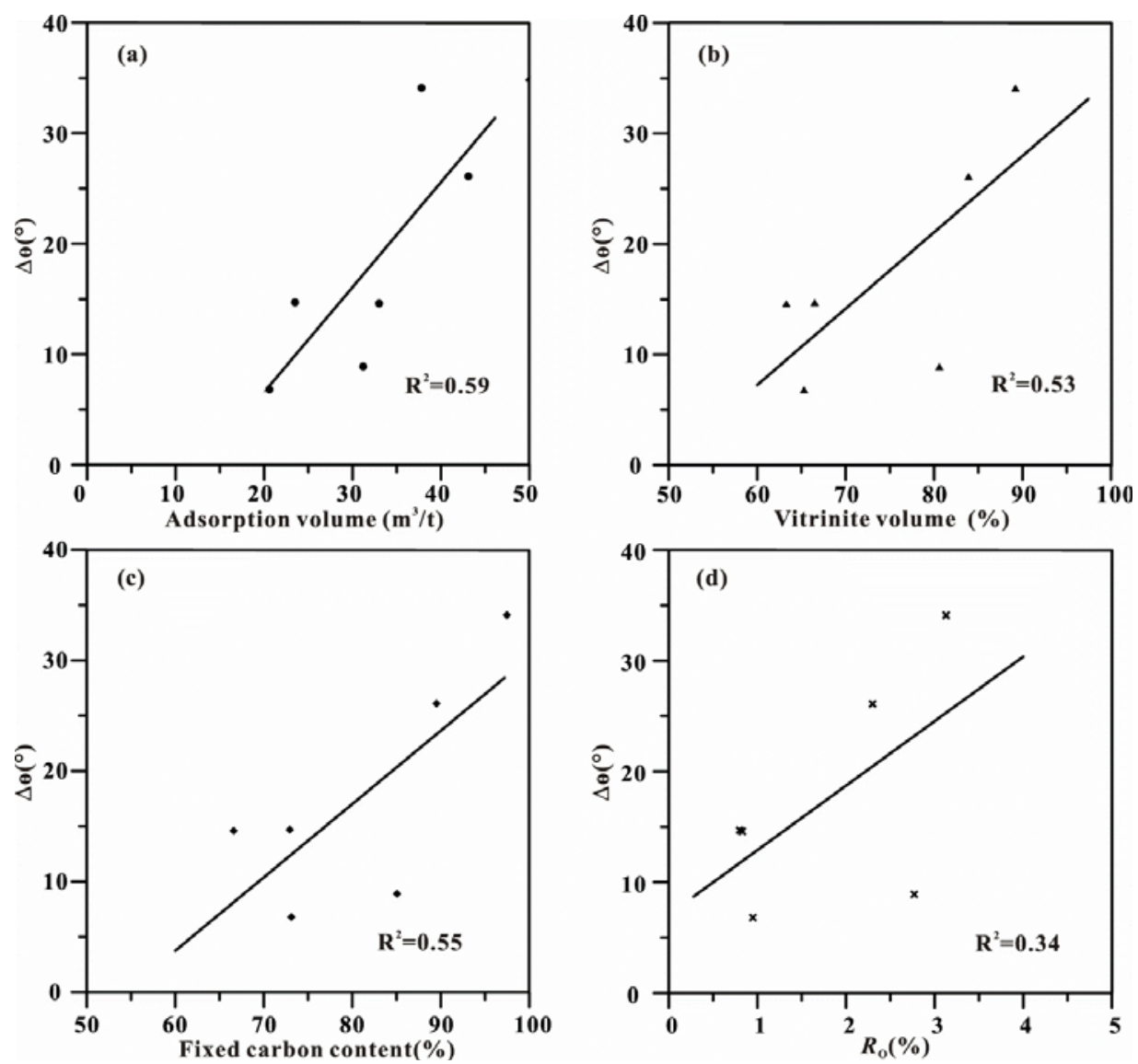

Fig. 13. The relationship between $\Delta \theta$ and a- $\mathrm{CO}_{2}$ adsorption capacity; b-vitrinite volume content of coal; c-fixed carbon content of coal; d-mean maximum vitrinite reflectance in oil $\left(R_{\mathrm{o}}\right)$. 

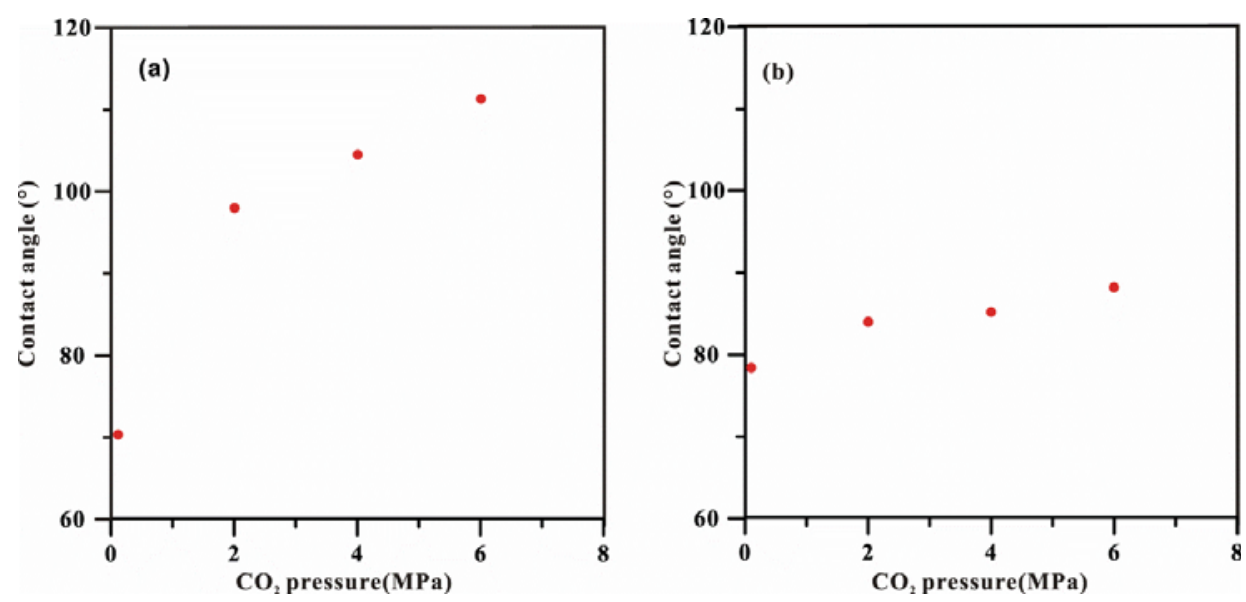

Fig. 14. The contact angle increases with increasing $\mathrm{CO}_{2}$ pressure (a-WTP; b-SYQ)

According to previous studies (Kaveh et al., 2011; Sakurovs and Lavrencic, 2011; Siemons et al., 2006), three factors affect the water-coal wetting behavior with increasing $\mathrm{CO}_{2}$ pressure, as shown in Fig. 15. The first one is the $\mathrm{CO}_{2}$ adsorption capacity of coal. As discussed above, coal with higher $\mathrm{CO}_{2}$ adsorption capacity is more $\mathrm{CO}_{2}$-wet. The increase of $\mathrm{CO}_{2}$ pressure leads to the more $\mathrm{CO}_{2}$-wet (Fig. 15a). Moreover, similar trends in the literature data on $\mathrm{CO}_{2}$ adsorption (Busch et al., 2003) also explain why the increased rate of contact angle is evident for pressures of 0.1-2 $\mathrm{MPa}$ in this study. The second factor is the change of interfacial tension with $\mathrm{CO}_{2}$ pressure (Fig. 15b). Arif et al. (2016) indicated that the $\delta_{\mathrm{sg}}$ of coal- $\mathrm{CO}_{2}$ decreases with increasing $\mathrm{CO}_{2}$ pressure (Fig. 15b). According to Eq. (4), surface wettability tension decreases with increasing $\mathrm{CO}_{2}$ pressure. The third factor is $\mathrm{CO}_{2}$ solution in water. The dissolution of $\mathrm{CO}_{2}$ in water can decrease the $\mathrm{pH}$, leading to the reduction of the negative charge density at the solid/water interface and thus reducing the electrokinetic potential of the coal particles (Ibrahim and Nasr-El-Din, 2016). Consequently, the $\delta_{\mathrm{ls}}$ of coal-water increases due to the negative contribution of the electrostatic component to surface energy, which causes the surface wettability tension to become less effective in $\mathrm{CO}_{2}$, according to Eq. (4). With increasing $\mathrm{CO}_{2}$ pressure, the $\mathrm{CO}_{2}$ solubility increases, leading (Ibrahim and Nasr-El-Din, 2016).
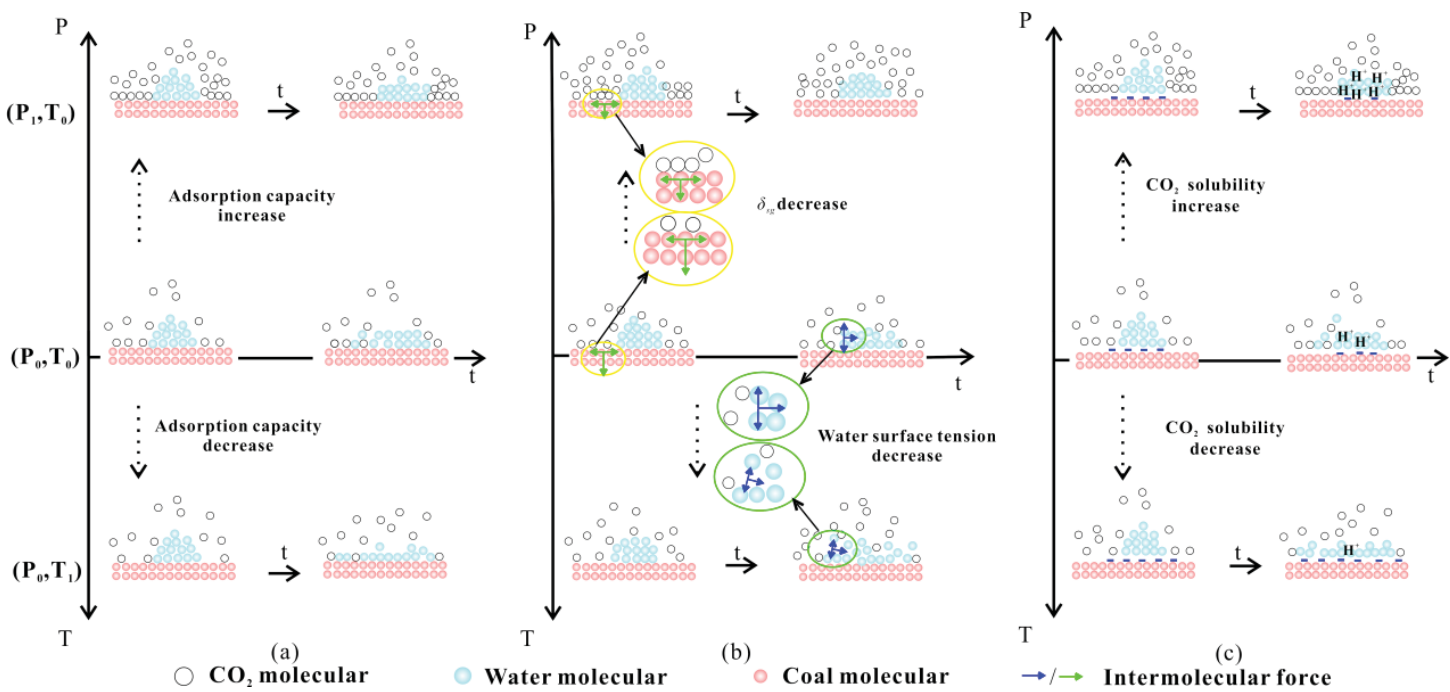
Fig. 15. The factors affecting the water-coal wetting behavior with pressure and temperature (a) $\mathrm{CO}_{2}$ adsorption; (b) interfacial tension; (c) $\mathrm{CO}_{2}$ dissolution

\subsubsection{The effect of temperature on water and $\mathrm{CO}_{2}$ wettability}

As shown in Fig. 16, for both anthracite and bituminous coal at $4 \mathrm{MPa} \mathrm{CO}_{2}$, the contact angle of water calculated by Eq. (5) decreases with increasing temperature. It can be concluded that high temperature decreases the effect of $\mathrm{CO}_{2}$ on the water wettability of coal. For anthracite coal, there is a clear decrease from $125.5^{\circ}$ to $110.7^{\circ}$ with increasing temperature. However, for bituminous coal, the contact angle first decreases from $75.3^{\circ}$ to $71.1^{\circ}$ and then becomes almost constant. The impact of temperature on coal wettability after $\mathrm{CO}_{2}$ treatment can also be explained by the three factors shown in Fig. 15. First, the increasing temperature reduces $\mathrm{CO}_{2}$ wettability because high temperature reduces the $\mathrm{CO}_{2}$ adsorption capacity of coal. The reduced $\mathrm{CO}_{2}$ affinity makes coal more water-wet (Kaveh et al., 2011; Sakurovs and Lavrencic, 2011; Siemons et al., 2006; Ibrahim and Nasr-El-Din, 2016) (Fig. 15a). Second, increasing temperature induces the reduction of water surface tension (Gittens' research, 1969; Chiquet et al., 2007; Zhou et al., 2017) (Fig. 15b). The water contact angle decreases with temperature at $0.1 \mathrm{MPa}$ without the solution and adsorption of $\mathrm{CO}_{2}$ (Arif et al., 2016). Additionally, the decrease in contact angle with temperature has been reported for pure minerals such as mica or quartz (Chiquet et al., 2007). Finally, the water solubility of $\mathrm{CO}_{2}$ decreases with temperature (Wiebe and Gaddy, 1940); thus, reduced $\mathrm{H}^{+}$ concentrations can result in the increase of the water-wetting behavior of coal (Fig. 15c).
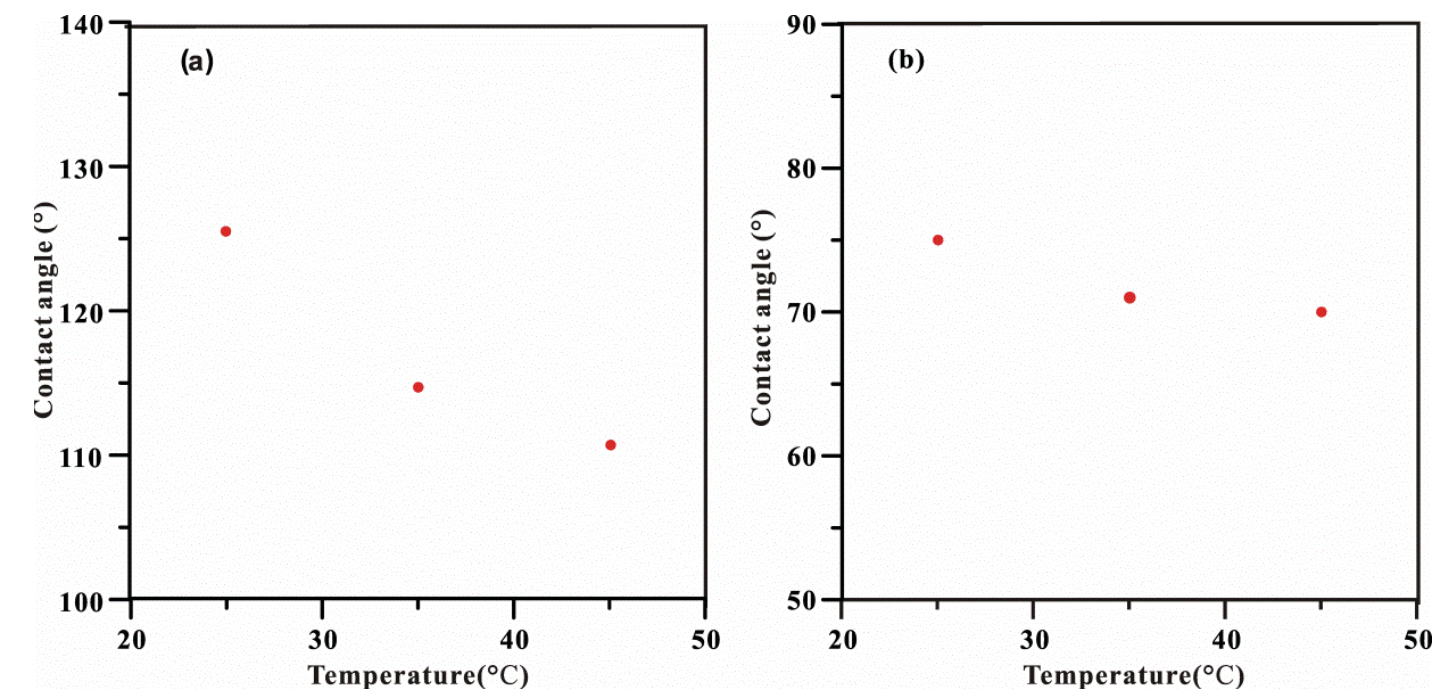

Fig. 16. The contact angles decrease with increasing temperature (a-GH; b-FK)

\section{Implications}

The NMR provides a novel technique to measure the water and $\mathrm{CO}_{2}$ wettability of coal during $\mathrm{CO}_{2}$ sequestration that can simulate in situ reservoir conditions. We determine the wettability of coal by fitting the $T_{2 \mathrm{~g}}$ of $\mathrm{P} 3$ and its contact angle against the coal surface. This method can also be used in other porous media, such as gas shale, although a different fitting formula must be established based on a series of measurements of NMR spectra and the contact angles of other 
porous media.

496

497

498

499

500

501

502

503

504

505

506

507

508

509

510

511

512

513

514

515

516

517

518

519

520

521

522

523

524

525

526

527

528

529

530

531

532

533

534

535

The experimental data show that $\mathrm{CO}_{2}$ storage in coal seams is strongly influenced by coal properties, gas pressure and reservoir temperature. The coal with high $\mathrm{CO}_{2}$ adsorption capacity, high fixed carbon content and high vitrinite content shows more $\mathrm{CO}_{2}$-wetting. Considering the fact that the sequestration capacity of coal is mainly dominated by $\mathrm{CO}_{2}$ adsorption and the $\mathrm{CO}_{2}$ wettability of coal, coal with high $\mathrm{CO}_{2}$ adsorption capacity is more suitable for trapping $\mathrm{CO}_{2}$. Therefore, $\mathrm{CO}_{2}$ will occupy the micropores and water will occupy larger pores after $\mathrm{CO}_{2}$ injection. Consequently, $\mathrm{CO}_{2}$ will be distributed more uniformly in micropores and displace more methane and water. In addition, high $\mathrm{CO}_{2}$ pressure and low reservoir temperature increase the $\mathrm{CO}_{2}$ wettability of coal for both anthracite and bituminous coals. Consequently, high pressure and low temperature are two favorable factors for CGS and $\mathrm{CO}_{2}$-ECBM.

\section{Conclusion}

In this study, water was dropped into coal powder and measured by NMR technology to determine the wettability of coal. The bulk water peaks of nine coal samples increase and shift to smaller $T_{2}$ values after the addition of water. The changes of the $\mathrm{P} 3$ position were quantitatively analyzed to determine the water wettability of coal. The wettability of coal from NMR results matches well with the contact angle measurements on coal discs. Although there are some uncertainties in the experiment, NMR provides a quantitative method to determine coal wettability.

NMR also provides a way to study water- $\mathrm{CO}_{2}$ wettability with regard to coal properties, pressure and temperature. $\mathrm{CO}_{2}$ injection can weaken the water wettability by replacing water from coal surface with adsorbed $\mathrm{CO}_{2}$. Meanwhile, high $\mathrm{CO}_{2}$ pressure increases the $\mathrm{CO}_{2}$ wettability, and high temperature decreases the effect of $\mathrm{CO}_{2}$ on the water wettability of coal. The change of water-coal wetting behavior with injection of $\mathrm{CO}_{2}$, is resulted by three factors: change of $\mathrm{CO}_{2}$ adsorption capacity of coal, change of interfacial tension, and dissolution of $\mathrm{CO}_{2}$ in water. Analyzing wettability with NMR has the potential to target coal seams for $\mathrm{CO}_{2}$ sequestration. Additionally, it can be used to determine the wettability of gas shale during $\mathrm{CO}_{2}$ sequestration into gas shale reservoirs.

\section{Acknowledgments}

We acknowledge financial support from the National Natural Science Foundation of China (41472137), the Key Research and Development Projects of The Xinjiang Uygur Autonomous Region (2017B03019-01), and the National Major Research Program for Science and Technology of China (2016ZX05043-001), and the Royal Society Edinburgh and National Natural Science Foundation China (NSFC 41711530129).

\section{Reference}

American Petroleum Institute, 1962. API recommended practices for laboratory testing of surface active agents for well stimulation, American Petroleum Institute, Production Department.

Amott, E., 1959. Observations relating to the wettability of porous rock. Pet. Trans. AIME. 216, 156-162.

Anderson, W. G., 1986. Wettability literature survey-Part 2: Wettability measurement. J. Pet. 
Technol., 38, 1246-1262.

537

538

539

540

541

542

543

544

545

546

547

548

549

550

551

552

553

554

555

556

557

558

559

560

561

562

563

564

565

566

567

568

569

570

571

572

573

574

575

576

Arif, M., Barifcani, A., Lebedev, M., Iglauer, S., 2016. $\mathrm{CO}_{2}$-wettability of low to high rank coal seams: implications for carbon sequestration and enhanced methane recovery. Fuel 181, 680689.

Arnold, B.J., Aplan, F.F., 1989. The hydrophobicity of coal macerals. Fuel 68, 651-658.

Benner, F.C., Dodd, C.G., Bartell, F.E., 1942. Evaluation of effective displacement pressures for petroleum oil-water silica systems. In: Drilling and Production Practice, New York, U.S.A.

Bobek, J.E., Mattax, C.C., Denekas, M.O., 1958. Reservoir rock wettability-its significance and evaluation. Pet. Trans. AIME. 213, 155-160.

Bortolotii, V., Macini, P., Falan, S., 2009. Combined spatially resolved and non-resolved ${ }^{1} \mathrm{H}$ NMR relaxation analysis to assess and monitor wettability reversal in carbonate rocks. In: International Petroleum Technology Conference, Doha, Qatar. SPE 13443.

Busch A., Gensterblum Y., Krooss B. M., 2003. Methane and $\mathrm{CO}_{2}$ adsorption and desorption measurements on dry Argonne premium coals: pure components and mixtures. Int. J. Coal Geol.55, 205-224.

Busch, A., Gensterblum, Y., 2011. CBM and $\mathrm{CO}_{2}$-ECBM related sorption processes in coal: A review. Int. J. Coal Geol. 87:49-71.

Chalbaud, C., Robin, M., Egermann, P., 2006. Interfacial tension data and correlations of brine$\mathrm{CO}_{2}$ systems under reservoir conditions. In: SPE Annual Technical Conference and Exhibition, San Antonio, Texas. SPE 102918.

Chaturvedi, T., Schembre, J.M. Kovscek A.R., 2009. Spontaneous imbibition and wettability characteristics of Powder River Basin coal. Int. J. Coal Geol.77, 34-42

Chiquet P., Broseta D., Thibeau S., 2007. Wettability alteration of caprock minerals by carbon dioxide. Geofluids 7, 112-122.

Coates, G. R., Xiao, L. Z., Prammer, M. G., 1999. NMR logging principles and applications. Gulf Publishing Company, Houston.

Connolly, P. R. J., Vogt, S. J., Iglauer, S., May, E. F., Johns, M. L., 2017. Capillary trapping quantification in sandstones using NMR relaxometry. Water Resour. Res. 53, 7913-7932.

Donaldson, E.C., Thomas, R.D., Lorenz, P.B., 1969. Wettability determination and its effect on recovery efficiency. Soc. Pet. Eng. J. 9, 13-20.

Fuerstenau, D.W., Williams, M.C., Narayanan K.S., Oiao, J.L., 1987. Assessing oxidation and the wettability of coal by a film flotation technique. In: 193rd ACS National meeting of the American Chemical Society, Denver, USA. Apr 5.

Gao, Z.Y., Hu, Q.H., 2016. Wettability of Mississippian Barnett Shale samples at different depths: investigations from directional spontaneous imbibitions. AAPG Bull. 100, 101-114.

Gentzis, T., 2000. Subsurface sequestration of carbon dioxide-an overview from an Alberta (Canada) perspective. Int. J. Coal Geol., 43, 287-305

Gittens, G. J., 1969. Variation of surface tension of water with temperature. J. Colloid Interface Sci. 30, 406-412

Guo, R., Kantzas, A., 2009. Assessing the water uptake of Alberta coal and the impact of $\mathrm{CO}_{2}$ injection with low-field NMR. J. Can. Pet. Technol. 48: 40-46. 
Han, F., Busch, A., Wageningen, N., Yang, J., Liu, Z., Krooss, B.M., 2010. Experimental study of gas and water transport processes in the inter-cleat (matrix) system of coal: Anthracite from Qinshui Basin, China. Int. J. Coal Geol.81, 128-138

580

581

582

583

584

585

586

587

588

589

590

591

592

593

594

595

596

597

598

599

600

601

602

603

604

605

606

607

608

609

610

611

612

613

614

615

616

617

He, Y.B., Laskowski, J.S., 1992. Contact angle measurements on discs compressed from fine coal. Coal Prep. 10, 19-36.

Horsley, R.M., Smith, H.G., 1951. Principles of coal flotation. Fuel 30, 54-63

Howard, J.J., Kenyon,W.E., Straley, C., 1993. Proton-magnetic resonance and pore-size variations in reservoir sandstones, SPE Form.Eval.3, 194-200.

Ibrahim, A. F., Nasr-El-Din, H. A., 2016. Effect of water salinity on coal wettability during $\mathrm{CO}_{2}$ sequestration in coal seams. Energy Fuel 30, 7532-7542.

Iglauer, S. 2017. $\mathrm{CO}_{2}$-water-rock wettability: variability, influencing factors and implications for $\mathrm{CO}_{2}$ geo-storage. Acc. Chem. Res. 50, 1134-1142.

Iglauer, S., Pentland, C.H., Busch, A., 2015. " $\mathrm{CO}_{2}$ wettability of storage and seal rock and implications for carbon geo-storage”. Water Resour. Res. 51,729-774.

Jayaweera, S.A.A., Moss, J.H., Thwaites, M.W., 1989. The effect of particle size on the combustion of weardalecoal. Thermochim.Acta.152, 215-225.

Johannesen, E.B., Riskedal, H., Tipura, L., 2007. Wettability characterization by NMR $T_{2}$ measurements in Edwards limestone rock. In: International Symposium of the Society of Core Analysts, Calgary, Canada.

Johnson, R.E., Dettre, R.H., 1969. Wettability and contact angles. Surf. Colloid Sci. 2, 85-153.

Kaveh, N.S., Rudolph, E.S.J., Wolf, K.H.A.A., Ashrafizadeh, S.N., 2011. Wettability determination by contact angle measurements: hvbB coal-water system with injection of synthetic flue gas and $\mathrm{CO}_{2}$. J. Colloid Interface Sci. 364, 237-247.

Kaveh, N.S., Wolf K.H., Ashrafizadeh S.N., Rudolph E.S.J., 2012. Effect of coal petrology and pressure on wetting properties of wet coal for $\mathrm{CO}_{2}$ and flue gas storage. Int. J. Greenh. Gas Con. 11, 91-101.

Keller, D.V., 1987. The contact angle of water on coal. Colloids Surf. 22, 21-35.

Kenyon, W.E., Day, P.I., Straley, C., Willemsen, J.F. 1988. A three part study of NMR longitudinal relaxation properties of water saturated sandstones. SPE Form. Eval. 3, 622-636.

Lowden, B.D., Porter, M.J., Powrie, L.S., 1988. $T_{2}$ relaxation time versus mercury injection capillary pressure: implications for NMR logging and reservoir characterisation. In: European Petroleum Conference, Hague, Netherlands. SPE 50607.

Manalo, F., Kantzas, A., 2003. Soil wettability as determined from using low-field nuclear magnetic resonance. Environ. Sci. Technol. 37, 2701-2706.

Meng, Q., Liu, H., Huang, J.A., 2017. A critical review on fundamental mechanism of spontaneous imbibition and the impact of boundary condition, fluid viscosity and wettability. Adv. Geo-energ. Res. 1, 1-17.

Orumwense, F.O., 1998. Estimation of the wettability of coal from contact angles using coagulants and flocculants, Fuel 77, 1107-1111.

Ozdemir, E., 2009. Modeling of coal bed methane (CBM) production and $\mathrm{CO}_{2}$ sequestration in coal seams. Int. J. Coal Geol.77, 145-152 
620

621

622

623

624

625

626

627

628

629

630

631

632

633

634

635

636

637

638

639

640

641

642

643

644

645

646

647

648

Saghafi, A., Javanmard, H., Pinetown, K., 2014b. Study of coal gas wettability for $\mathrm{CO}_{2}$ storage and $\mathrm{CH}_{4}$ recovery. Geofluids 14, 310-325.

Saghafi, A., Pinetown, K., Javanmard H., 2014a. Gas wettability of coal and implications for gas desorption and drainage. In: 14th Coal Operators' Conference, University of Wollonong, Australia.

Sakurovs, R., Lavrencic, S., 2011. Contact angles in $\mathrm{CO}_{2}$-water-coal systems at elevated pressures. Int. J. Coal Geol. 87, 26-32.

Siemons, N., Bruining, H., Castelijns, H., Wolf, K.H., 2006. Pressure dependence of the contact angle in a $\mathrm{CO}_{2}-\mathrm{H}_{2} \mathrm{O}-$ coal system. J. Colloid Interface Sci. 297, 755-761.

Sun, X., Yao, Y., Liu, D., Elsworth, D., Pan, Z., 2016. Interactions and exchange of $\mathrm{CO}_{2}$ and $\mathrm{H}_{2} \mathrm{O}$ in coals: an investigation by low-field NMR relaxation. Sci.Rep. 6, 19919.

Wei, D., Chander, S., Hogg, R., 1992. Distribution of wettability of coal. Int. J. Coal Prep. Util. 10, 37-45.

Wiebe, B.Y., Gaddy, V.L., 1940. The solubility of carbon dioxide in water at various temperatures from 12 to $40^{\circ}$ and at pressures to 500 atmospheres. J. Am. Chem. Soc. 62, 815-817.

Xu, M., Dehghanpour, H., 2014. Advances in understanding wettability of gas shales. Energy Fuels 28, 4362-4375.

Yao, Y.B., Liu, D.M., 2010. Petrophysical characterization of coals by low-field nuclear magnetic resonance (NMR). Fuel. 89, 1371-1380.

Yao, Y.B., Liu, D.M., Xie, S.B. 2014. Quantitative characterization of methane adsorption on coal using a low-field NMR relaxation method. Int. J. Coal Geol. 131, 32-40.

Young,T.,1805.An Essay on the Cohesion of Fluids. Philos. Trans. R. Soc. Lond. 95, 65-87.

Zhang, G.Q., Huang, C.C., Hirasaki, G.J., 2000. Interpretation of wettability in sandstones with NMR analysis. Petrophysics 41, 223-267.

Zhang,Y., Lebedev, M., Sarmadivaleh, M., Barifcani, A., Iglauer, S., 2016. Swelling-induced changes in coal microstructure due to supercritical $\mathrm{CO}_{2}$ injection. Geophys. Res. Lett. 43, 9077-9083.

Zhou, G., Qiu, H., Zhang, Q., Xu, M., Wang, J., Wang, W., 2016. Experimental investigation of coal dust wettability based on surface contact angle. J. Chem. 9452303.

Zhou, Y., Hatzignatiou, D. G. and Helland, J. O., 2017. On the estimation of $\mathrm{CO}_{2}$ capillary entry pressure: Implications on geological CO2 storage, Int. J. Greenh Gas Con, 63, 26-36. 